\title{
التنظيم الدستوري والقانوني \\ لأطراف عقد تفويض المرفق العام والمستفيدين هنه
}

Organization of the constitutional and legal framework for the parties to contract delegating public utility and the rights of beneficiaries

$$
\begin{aligned}
& \text { shel } \\
& \text { د د فرحان نزال احميد المساعيد } \\
& \text { أستاذ القانون الدستورى والإدارى } \\
& \text { كليتة القانون جامعتَآل البيت - المفرق -الأردن }
\end{aligned}
$$


تمارس الادارة اعمالا قانونية باعتبار ها سلطة ادارية، وقد تكون هذه الاعمال

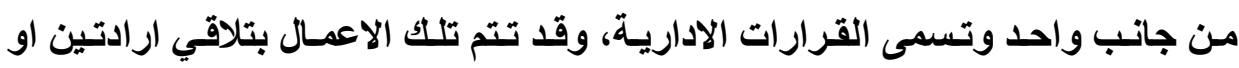

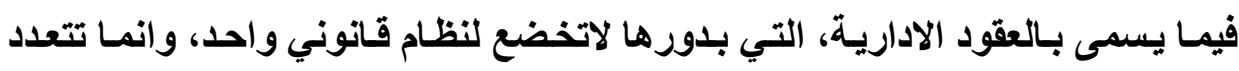

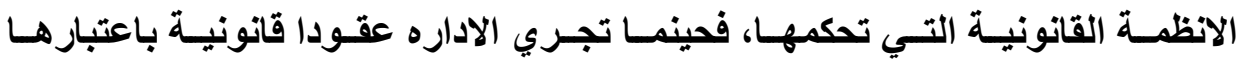

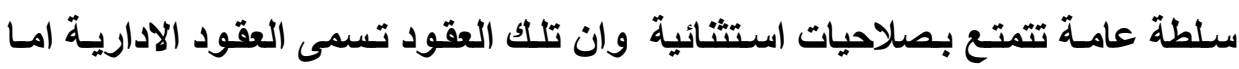

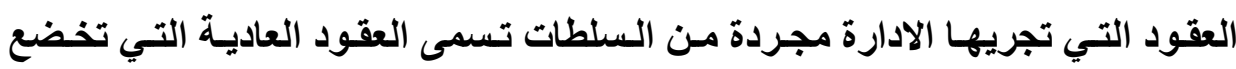

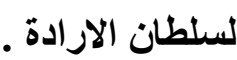

وعقود تفويض المرافق العامـة عقودا اداريـة من كامل الوجوه، بحيث تجريها

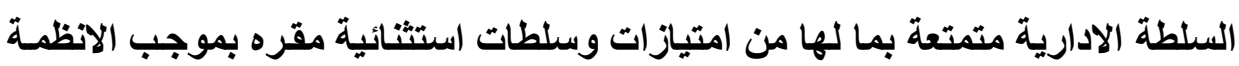

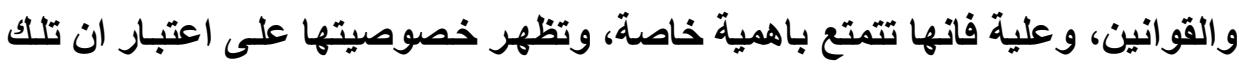
العقود تؤدي الى اشباع حاجات الجمهور الضرورية

وكغير ها من العقود، لاتقوم الا بوجود أطراف رئيسة لها، وهذه الأطراف تتمثل

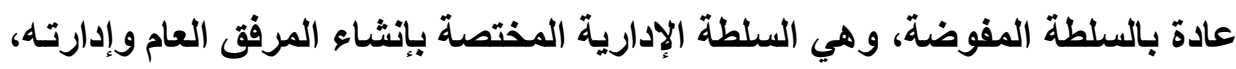

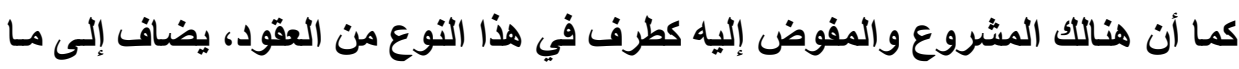

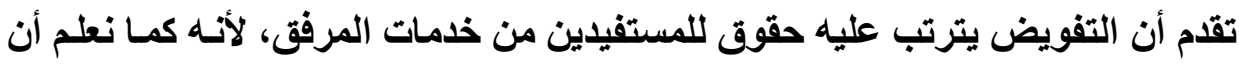

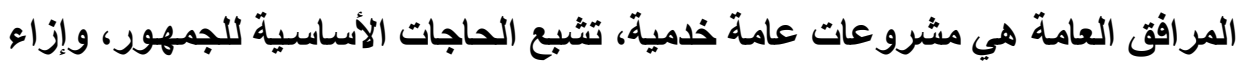

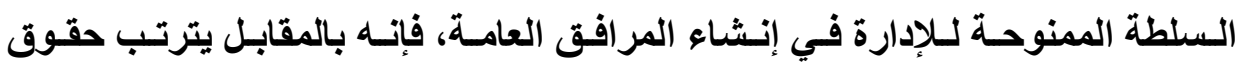

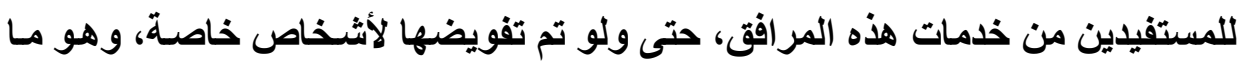
يمنح المستفيدين والمستهلكين حقوق، كحقهم في الطعون التي يقدمونها للدى القضاء الإداري المختص وتتعلق بالمر افق المفوضة، ويتم بيان ذلك من خلال: 


\section{أولاً: التعريف بموضوع البحث:}

يوجد في عقود التفويض للمرفق العام عدة أطراف رئيسة، ولا يمكن تجاهلها بحال من الأحوال وهي تعتبر بمثابة أركان للعقد ولا يتصور وجود عقد الفون تفويض مرفق

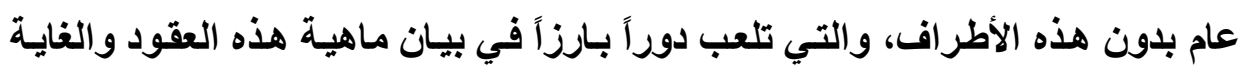
المتحققة منها، ومـا هي الحاجة الملحة لإبرام هذه العقود، وهو مـا نلاحظه في هذه

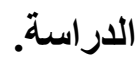

ثانيًا: هشكلة البحث (الغرض هنه):

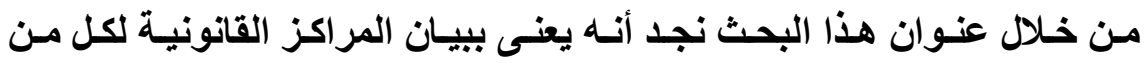
:أطراف عقود تفويض المرفق العام وبحقوق المستفيدين، حيث أن أطراف هذه العقود والتي تتمثل في السلطة المفوضة والمشروع المفوض إليه والمستفيدين، هي التي تحدد معـالم العلاقة القانونيـة التي تربط هذه الأطراف بيعضها، وتحدد صـلاحياتها وحقوقها، وكيفيـة الاستفادة مـن الطعون القضائية المترتبـة على المرافق المـراد تفويضها، ومن هنا فإن هنا الدراسة تهاف إلى الإجابة على التساؤلات التالية: ا- ها هي اطراف عقود تفويض المرنق العام؟

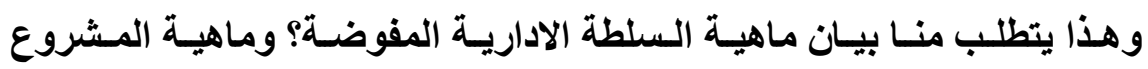
المفوض إليه؟ وهل يجوز التفويض لشركات القطاع العام والخاص؟ ومـا مدى جواز التفويض الفرعي للمرفق العام؟ إن r- هن هم المستفيدين هن المرفق العام؟ وها هي حقوقهم؟ وأيضاً هذا يتطلب منا بيان من هم المستفيدين من خدمة المرفق العام؟ ومـا هي حقوقهر؟ ومـا هـي طعون المستفيدين مـن المرفق العسام؟ ومـا هو الوضسع القـانوني 
للمستفيدين مـن خدمات المرفق العـام عند تطبيق قـانون الاستهلاك وقـانون المرافق العام؟ وما هو موقفنا من ذلك؟؟

\section{ثالثًا: أسباب اختيار الدراسة:}

هنالك العديد من الأسباب التي دفعتني لاختيار هذا الموضوع والبحث فيه ولعل أهمها: 1 ـ الدور الكبير الذي تلعبه أطراف هذه العقود في تحديد الطبيعة القانونية لها. r- إن أطراف هذه العقود تحدد صلاحيات السلطة المفوضة والمشروع المفوض إليه. والثخص المفوض إليه، وهو الأمر الذي ينشأ عنه عدة علاقات قانونية متصلة ومتسلسلة، وهو الأمر الذي يجعل من بحثها ودراستها، الخروج بنقاط قانونية مستحدثة وعلى جانب من الأهمية في هذه المواضيع. بـ تركيز هذا البحث على دراسة قانون الاستهلاك وقانون المرافق العامـة، وهو أمر حديث نسبياً، وتندر فيه المراجع والمصادر. ع ـ طبيعة الطعن المقدم من قبل المستفيدين من خدمات المرفق، تجعل منـه طريق قضائي لتصويب وضع المرفق وتحسين خدماتـه، ورقابـة على السلطة المفوضـة بعدم التعسف في استعمال حقها.

\section{رابهًا: هنهـمية البحث:}

اعتمد الباحث على المنهج القانوني التحليلي المتمثل في استعراض النصوص الاستورية والقانونية المتعلقة بموضوع البحث وتحليلها ومقارنتها، وموقفنا من ذلك، وقد اعتمدت على القانون الفرنسي وموقف القضاء الإداري الفرنسي من ذلك، وكذلك القانون المصري والسوري،والاردني والقضاء الإداري في كل منهما. 


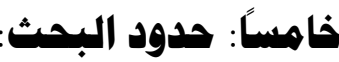

ـ الحسود الموضسوعية: يعسالج البحث موضسعات محددة تقتصر علـى بيـان الاطر

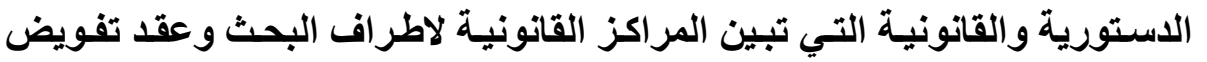

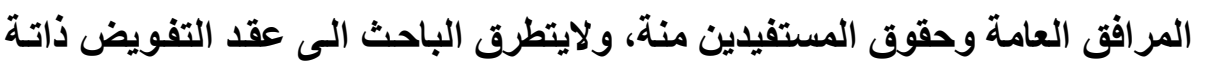

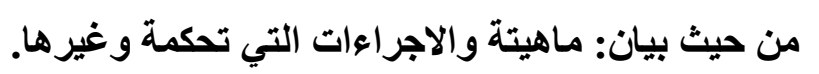

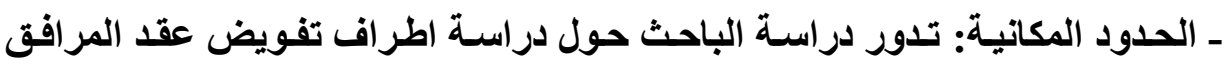

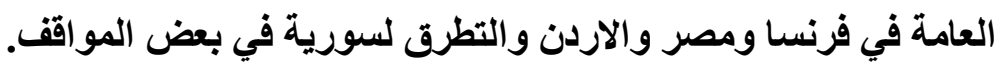

ـ اما الحدود الزمانية : تتضمن التثريعات واحكام القضاء في الدول المقارنة.

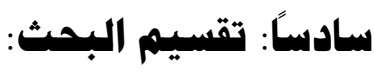

بما أن هذه الاراسة تقتصر على بيان الاطار الاستوري والقانوني ببيان المراكز

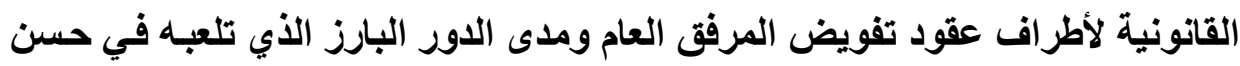

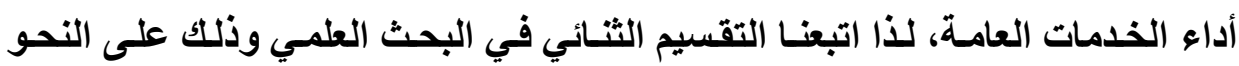
التالي: - (ل)

المبحث الأول: أطراف عقود تفويض المرفق العام.

المطلب الأول: السلطة الادارية المختصه بانشاء المرفق العام وادارتة.

المطلب الثاني: المشروع المفوض إليه.

المبحث الثاني: المستفيدون من المرفق العام.

المطلب الأول: حقوق المستفيدين وطعونهم في مجال تفويض المرفق العام.

المطلب الثاني: المستفيدون بين قانون الاستهلاك وقانون المرافق العامة.

الخاتمـة: وعرضنا فيها لأهم النتائج التـي توصلتا إليها من خـلال هذه الاراسـة مـع الإثارة إلى بعض التوصيات والمقترحات.

مجلت البحوث القانونيت والإقتصاديت 


\section{المبحث الأول \\ أطراف عقود تفويض المرفق العام}

التفويض أجراء أداري يستطيع بموجبة صاحب الاختصاص الاصيل بتخويل موظف

اخر او جهة ادارية اخرى صلاحيات اتخاذ بعض الاعمال القانونية بشروط خاصة ومن اجل هدف معين (')، وهناك فارق بين تفويض السلطة وتفويض التوقيع والثروط التي تحكم كل

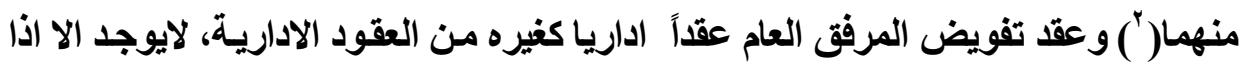
وجت الاركان الاساسية للعقود بصفة عامة وهي : السلطة الادارية المختصة باتشاء المرفق العام والمفوض إليه والمستفيدين، الذين يعتبرون من الغير بالنسبة لعقد تفويض المرفق

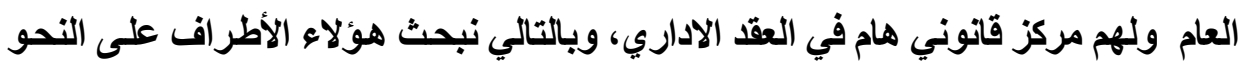

التالي: - n

\section{الاملب الأول: السلطة الادارية المختصة بانشاء المرفق العام وادارتة:}

تهذف المرافق العامة الى اشباع حاجـات المواطنين التي بلغت مبلفا هامـا من

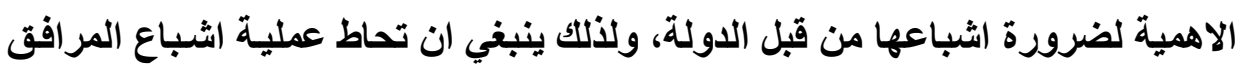

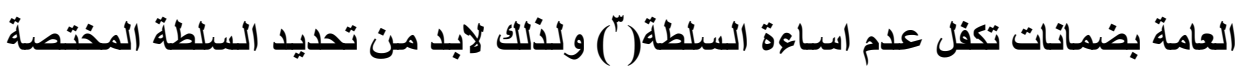
بمنح إدارة المرفق العام إلى شخص آخر خاص أو عام، وهذه السلطة لابد من تحديدها وذلك على النحو التالي: انع

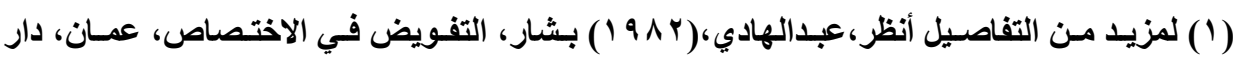

$$
\begin{aligned}
& \text { الفرقان، }
\end{aligned}
$$

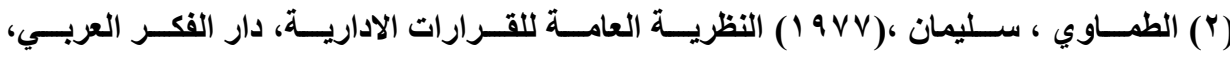

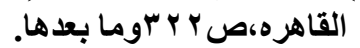

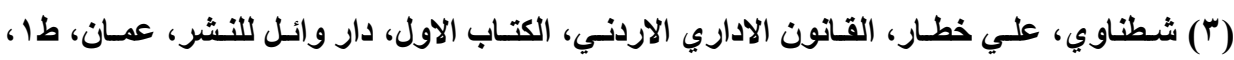

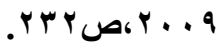

$$
\text { r }
$$




\section{الفرع الأول: السلطة الختصة بقرار تفويض المرفق العام:}

ينبغي في هذا المجال التمييز بين المرافق الوطنية والمحلية فيما يتعلق بانشاءها حيث سـارت التشريعات المقارنة على اكثر من نهج، فلاينعقد عقد تفويض المرفق العام إلا إذا صـدر قرار بـإبرام عقد التفويض مسن السلطة المختصة، والسلطة المختصة بإصداره هي تلك السلطة التي يـخل المرفق في اختصاصها، وتكون مسؤولة عن

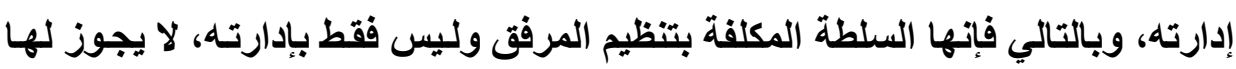
أن تقرر تفويضه إلا في الحالة التي تختلط فيها سلطة التنظيم مع سلطة الإدارة('). وتبنى مجلس الدولة الفرنسي رأياً مخالفًا لهذه القاعدة، تضمن أن اصطلاح

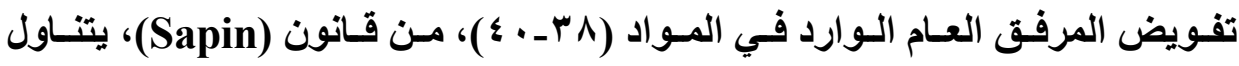
الحالات التي يكون فيها الثخص العام مكلقاً بمرفق عام، ويعهد بإدارة هذا المرفق إلى شخص يختاره، كمـا أنها يـلـخل في نطاق هذا القانون الحالات التي يتم فيها تفويض مرفق عام، بواسطة سلطة مسئولة عن تنظيم المرفق إلى شخص يعهد إلبه بمهــة

يتبين مما سبق ان السلطة المختصة بقرار تفويض المرفق العـام تكمن بالسلطة

الادارية والبرلمان حسبما يحدد الصلاحية الاستور ويوزع الاختصاصات مابينهمـا(بات).

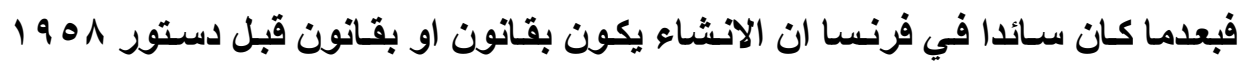

(1) J.B. Auby, C. maugue, J.C.P., 1994, precite, N 14.

(2) C.E., Assemble generale, 9 mars 1995, section des travaux publics, rapport precite, P. 399: " La Loi inclut dans son chanp d' application les cas ou Le service public est delegue par une authorite chargee de I' organization du service aune personne qui recoit pour mission de L'executter".

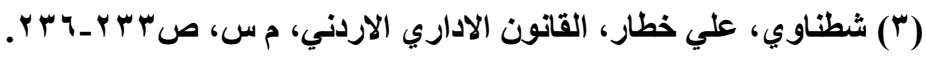


تغيرت الاحوال بحيث تضمن نصا(م ؟ ب) الامور التفصيلية التي ينظمها المشرع حصرا وترك ماعداها للادارة م(rV)('(').

وفي المملكة الاردنية الهاشـية فان للبرلمـان دورا مباشرا في انشاء المرافق

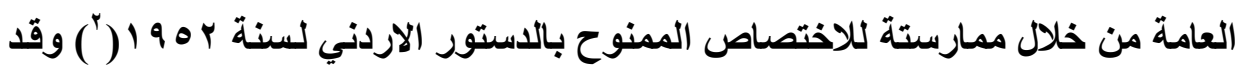
يمارس دورا غير مباشر من خلال سن قانون يحدد الملامسح العريضة لانشاء المرافق

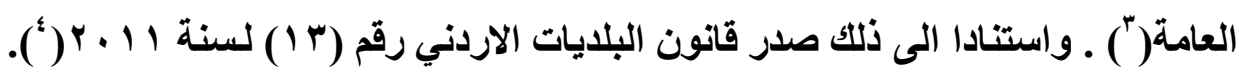
ولابد من الاشارة الى ان التعديلات الاستورية التي جرت على الاستور الاردنسي لسنة

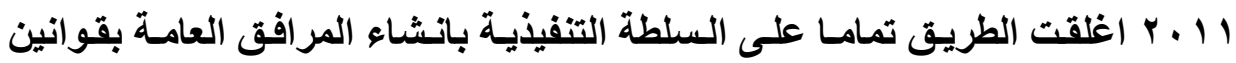
مؤقتة، بعدما درجت على ذلك سنوات عديدة ( ). ويلاحظ مما سبق ان البرلمان الاردني يتمتع بصلاحية في انثـاء المرافق العامـة فضلا عن صلاحيتة المحجوزة له في التصديق على الاعتمادات المالية اللازمـة لتسيير

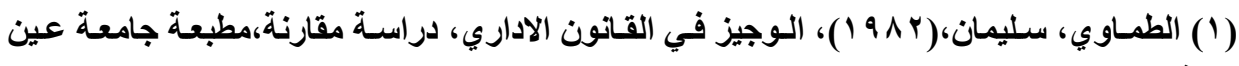

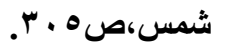

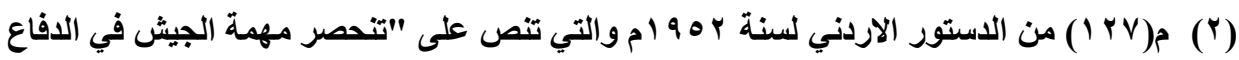

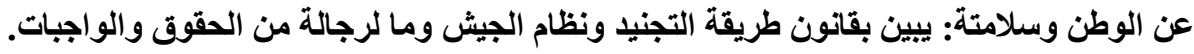

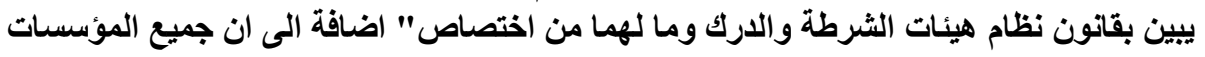

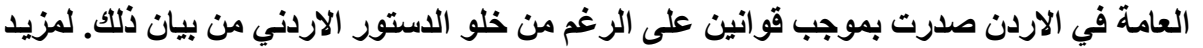

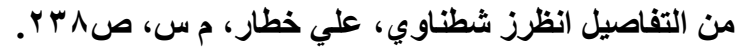

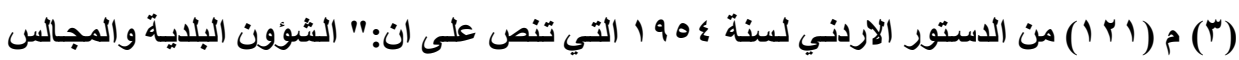

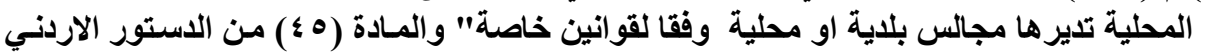

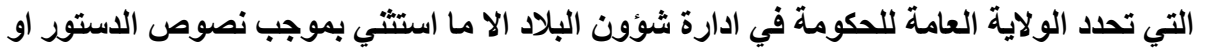

$$
\text { اي قانون اخر. }
$$

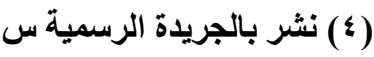

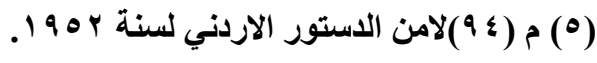

r مجلت البحوث القانونيت والإقتصاديت 
تلكك المرافق('). وعليـة فـان انشاء المرافق العامـة يكون بقانون او بنـاءا على قانون

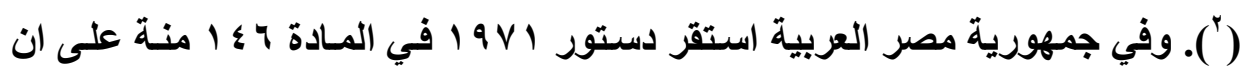

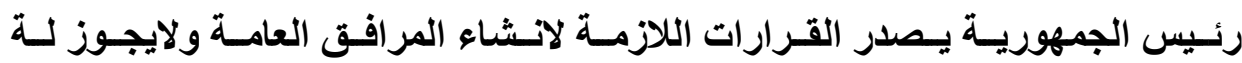

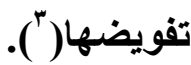

\section{الفرع الثاني: تمديد الساطة المفتصة بإدارة المرفق العام وتفويضه:}

ونتناول ذلك في كل من فرنسا، ومصر، وسورية،والاردن، وذلك على النحو التالي: أولاً: السلطة المختصة بإدارة المرفق العسام في فرنسا: ينعقد الاختصاص في إصدار قرار إبرام عقد تفويض المرفق العام، للشخص العـام المسؤول عن المرفق، وبالتـالي يمكن للاولـة والوحدات المحليـة والنقابـات التابعـة للمــن أن تكسون سـلطة تفويض. وبالنسبة للاولة فإن السلطة المختصة بقرار التفويض هي السلطة اللائحية، أي رئيس الوزراء والتطبيق الحديث لها هو تفويض الأستاذ الكبير لإقامة بطولـة العالم

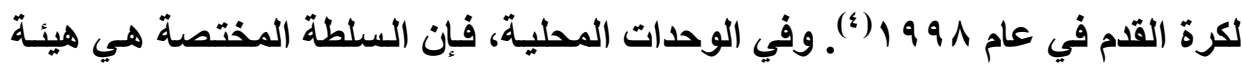
التقريز وليس السلطة التنفيذية للوحدة المحلية، وهيئة التقرير للوحدات المحلية هي المجالس البلدية، والمجالس العمومية، والمجالس الإقليمية(॰). وفي فرنسا نجد بأنه اعتباراً من صدور قانون اللامركزيـة عام ب ^و 1 ، لـم يعد إبـرام عقـود تفـويض المرافق العامـة المحليـة يتطلب موافقـة سـلطة الوصـاية، أي

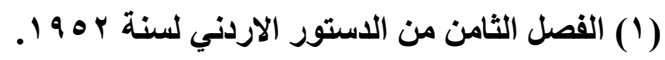

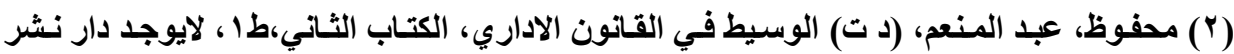

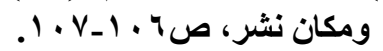

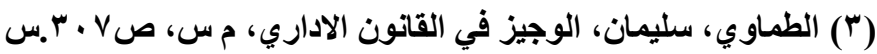

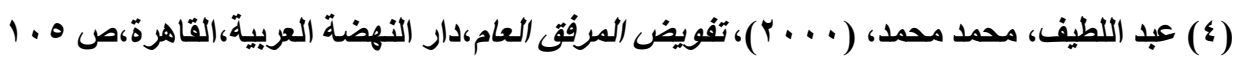

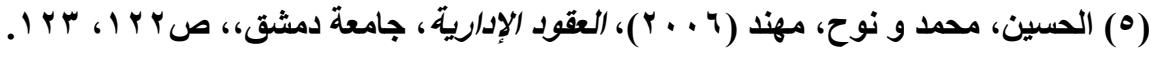


المحافظ('). وبالنسبة للنقابات التابعة للمدن، فـالقرار يصدر من اللجنـة النقابية وليس من المكتب(`)، ويتمتع الثخص المسئول عن المرفق بسلطة تقديرية لتقرير مـا إذا كـان المرفق يدار بالاستغلال المباشر أم بتفويضه للغير (").

وإذا كان قانون (Sapin) لا يطبق إلا على تفويض المرافق العامـة للأشخاص المعنوية للقانون العام، إلا أنه وفقاً للقانون الأوروبي، فِان جماعـات القانون الخـاص، والتي يتم تكوينها بين الأشخاص العامة أو منظمات القانون الخاص، والتي تنشأ بقصد إثباع حاجات ذات مصلحة عامة ليست لها طبيعة صناعية أو تجاريـة، يمكن أن تبرم مع مقاول امتياز أثـغال ،على أن يكون المقابل المـالي للمقاول هو استغلال المنشآت

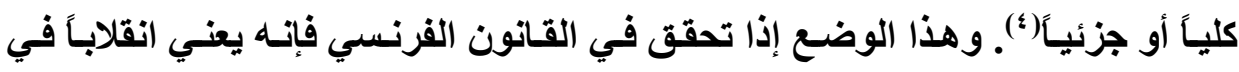
مفهوم تفويض المرفق العام، والذي يقوم على أساس أن يعهد شخص عام إلى شخص

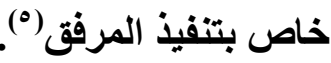
ثانياً: السلطة المختصة بتفويض المرفق العـام في مصر: إن تحديد نوع العقد في مصر هو الأي يتوقف عليه تحديد السلطة المختصة بتفويض المرفق العام"(") وفيما

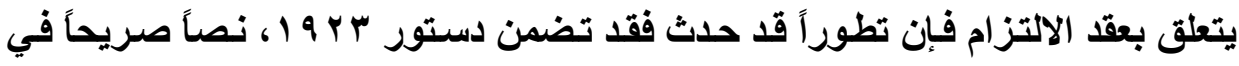

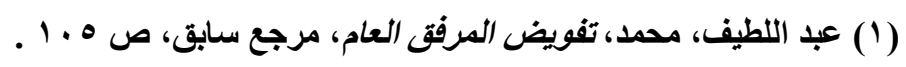

(2) C.E., 15 juin 1994, syndicab intercommoned des transport' ue La region de douai, Rec., P. 1033.

(3) C.E., 10 janvier 1992, Assocaiation des usagers del eau de pey, Rec., p. 13.

(4) ph. Terheyre, L.a nation de converntion de delegation precite, p. 590 .

(5) P. Delvolve, Les contradictions de La delegation de service public, precite, p. 687 .

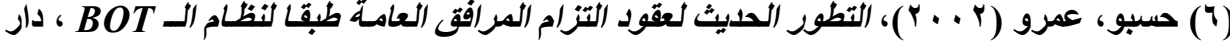

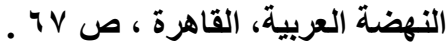

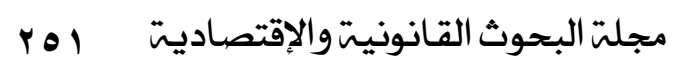


المـادة ( I I ) بشأن إصـار قـانون خـاص بمـنح كل التزام على حده، لكن دستور

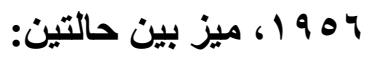

ا ـ الحالة الأولى: إذا كان الالتزام المراد منحه يتضمن احتكاراً، فيجب في هذه الحالة

$$
\text { صدور قانون في كل حالة على حده('). }
$$

r ـ الحالة الثانية: إذا كان الالتزام لا ينظوي على احتكار، فيكون منحه وفقاً للقانون أي بقرار من رئسيس الجمهوريـة بعد موافقة مجلس الأمـة، أمسا دستور

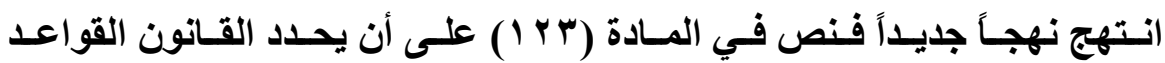
والإجراعات الخاصـة بمنح الالتزامـات المتعلقة باستغلال موارد الثروة الطبيعية

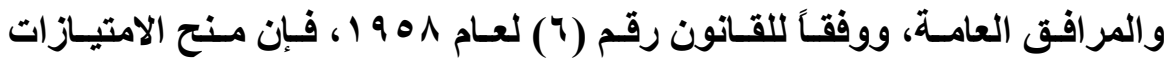
المتعلقة بـالمرافق العامـة يكون بقرار من رئسيس الجمهوريـة بعد موافقة مجلس الشعب() وهذه النصوص لا تفرق بين المرافق المحلية والمرافق القومية، إلا أنه قد أصـابها التعديل فيمـا يتعلق بمنح التزام المرافق المحليـة. فقد اشـترط قانون الإدارة المحلية موافقة المجلس الشعبي المحلي المختص على منح التزام استغلال

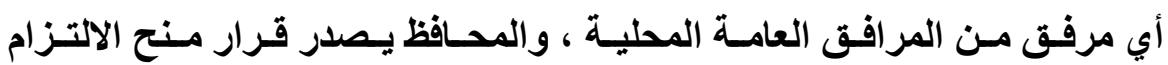
باعتباره رئيس جميع المرافق المحلية("). كما أن القوانين الصادرة مؤخراً في مصر والمتعلقة بمنح التزامـات المطارات

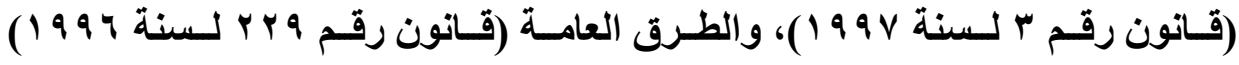

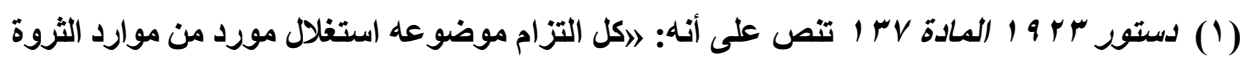

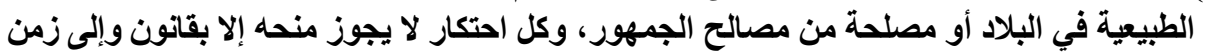

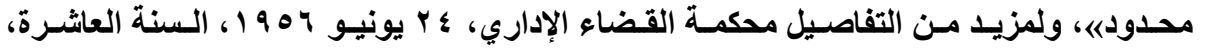

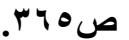

(Y) أبو زيد، محمد (19vV (1)، أثر التفويض في الاصطلاح الإداري، دار النهضة العربية، القاهرة.

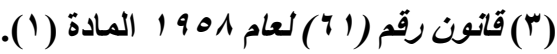


ومحطات الكهربـاء (قانون رقم . . 1 لسنة 999 1) ، اكتفت بـأن يصدر بمنح الالتزام وتحليـــ شـروطه وأحكامسه، قـرار مـن مجلـس الـوزراء بنــاء علـى اقتـراح الـوزير

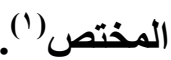

ويثور التساؤل التالي بخصوص النصوص التي تحكم التزامـات المرافق العامـة، وهو إذا كاتت الالتزامات الأكثر أهمية يتم منحها بقرار من مجلس الوزراء، فكيف يمكن أن يتم منتح الالتزامـات الأقل أهميـة بقرار من رئيس الجمهوريـة بعد موافقة مجلس الشعب؟ ومـن هنـا تبرز الحاجـة الماسـة لإعـادة توحيد الأحكام التي تخضع لها عقود

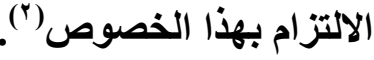
أمـا فيما يتعلق بعقود التفويض الأخرى، فإنـه يجب التمييز بين المرافق العامـة القومية والمرافق العام المحلية، ففي المرافق القومية فالوزير هو المسؤول عن إدارة المرافق التابعة لوزارته، وبالتالي فهو الذي يصدر قرار تفويض المرفق. أمسا السلطة المختصة بتنظيم المرافق العامة فهي رئيس الجمهورية)("). وفيما يتعلق بـالمرافق المحلية فإن الوحدات المحلية هي المسؤولة عن إدارة هـذه المرافق، حيث يـص قـانون الإدارة المحليـة على أن: التتـولى وحـدات الإدارة المحلية في حدود السياسة العامـة والخطة العامـة للاولـة إنشاء وإدارة جميع المرافق المداف 
العامـة الو اقعـة في دائرتهاه|"() وبالتـالي فالمجـالس المحلية هي السلطة المختصة بالتفويض في إدارة المرفق المحلي"(َ).

\section{ثالثً: السلطة المنتصة بإبرام عقود تفويض المرفق العام في سورية:}

نجد أنه في سورية بموجب المادة (VI) من الاستور، والتي سبق ذكرها، ينعقد الاختصاص في إبرام عقد الالتزام، للسلطة التنفيذية، شريطة موافقة مجلس الشعب، وذلك بالنسبة لعقود الالتزام المبرمة مع الثركات والمؤسسات الأجنبية، وعقد الالتزام

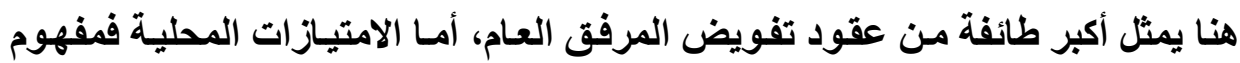

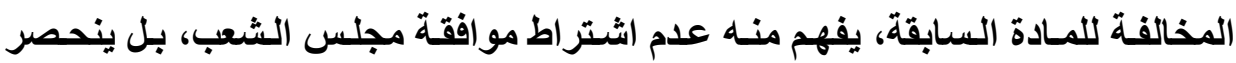
الاختصاص في السلطة التنفيذيـة. أمسا بالنسبة لعقود الأشـخاص العامـة اللامركزيـة، فيلاحظ أن المكتب التتفيذي للمحافظة يتولى تمثيل المجلس وتتفيذ قراراتـه(")، كما يختص هذا المكتب بإقرار مخططات ودفاتر المشاريع، وإجراءات المناقصات أو العقود بالتراضي ضمن الحدود والأحوال، التي تبين في اللائحة التنفيذية والقوانين النافذة( (4). فالمحافظ يرأس المكتب التنفيذي للمحافظة، وينفذ قراراته ويتقيد بهاء إهات.

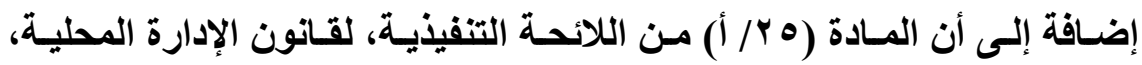

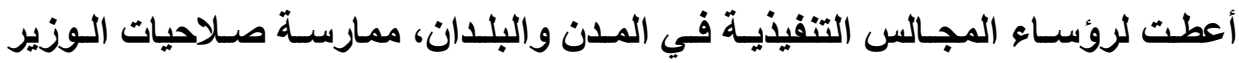

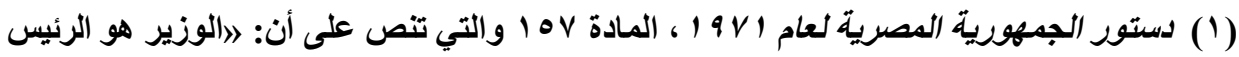

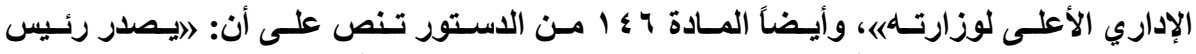

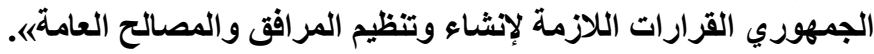

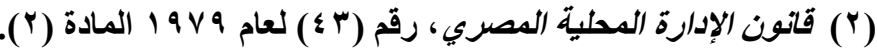

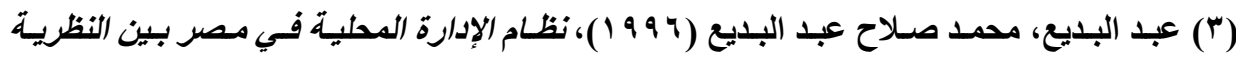

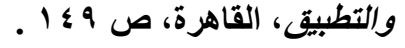

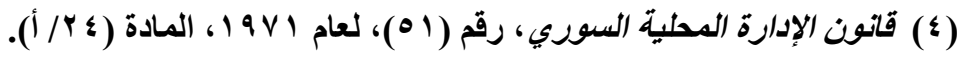

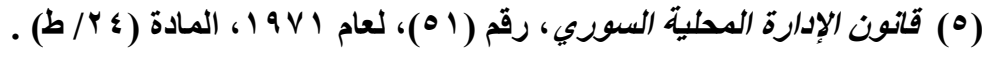


المختص بموجب نظام عقود هيئات القطاع الإداري، باستثناء الصلاحيات الممنوحة لرئيس المكتب التنفيذي لمجلس المحافظة في هذا المجال، كمـا أوضحت المسادة (Y^) من اللائحة، بأنه: (يتولى رئيس المكتب التنفيذي في القريـة الواحدة الريفية، بموجب

هذه اللائحة الصلاحيات الممنوحة لرئيس المكتب التففيذي في المدينة أو البلدة)('). إذاً من هذه النصوص نجد أن المشرع أعطى دوراً واسـعاً للمكتب التنفيذي، في نطاق إبرام عقود الإدارة المحلية في سورية، فبالنسبة لاختصاص المكتب التنفيذي لمجلس المحافظة، يلاحظ أن استعمال عبـارة إجراء المناقصات والعقود بالتراضسي، تحمل مدلول واسع يمتد ليثمل اختيار إجراء التعاقد، والإشراف على العملية التنفيذيـة لهذا الإجراء، وسلطة تقديرية في إبرام أو عدم إبرام العقد لَ). وهنالك من يرى بـأن للمكتب التنفيذي سلطة واسعة ، في نطاق العقود التي تبرمهـا البلدان والمـدن والقرى والوحدات الريفيـة، فرئيس المكتب التنفيـي يملتك سلطات واسعة في التعبيز عن إرادة هذه الوحدات، حيث يملك نفس سلطات الوزير المنصوص عليها في نظام عقود هيئات القطاع العام، وهذا يجعله ينفرد بـالتعبير عن إرادة هذه الوحدات، دون مشاركة المجلس الذي يتبع لـه المكتب التنفيذي ورئيسه، وذلك قياساً على صلاحية الوزير المختص الذي ينفرد في تقرير إبرام العقد. وهذا الأمر يجعل أن الاختصاص في التعبير عن إرادة الوحدة الإداريـة المحلية في سورية، عند إبرامها لعقودها، لا يندرج بين سلطتي التقريز والتنفيذ المعروفة في فرنسا، بل تنفرد جهة التنفيذ (المكاتب التنفيذية أو رؤساؤها)، بالنهوض بعبء لهاء هذا الاختصاص، ويرى ولير

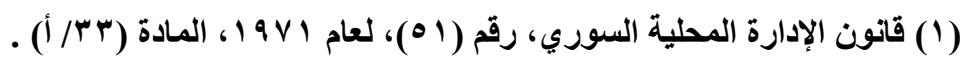

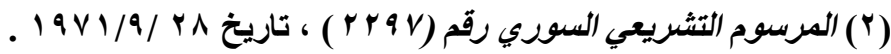

$$
\begin{aligned}
& \text { ros مجلت البحوث القانونيت والإقتصاديت }
\end{aligned}
$$


أصحاب هذا الرأي أن اتجاه المشرع هنـا غير مقبولاً، لأن المجالس المحلية هي التي تعبر عن الإرادة الحقيقية للوحدات المحلية(')

ونحن نتفق مع هذا الرأي لأن القول بعكس ذلكك يحصر الاختصاص في التعبير

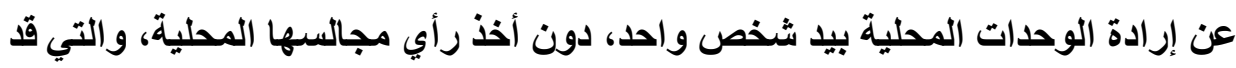

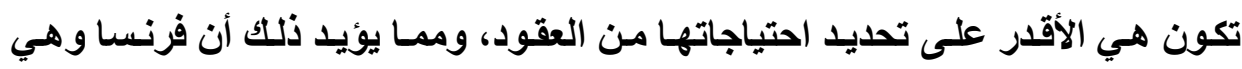
الدولة الرائدة في القانون الإداري، قد جعلت سلطة إبرام العقود الإداريـة تتلدرج بين سلطة تقريرية، وسلطة تنفيذية، وهذا الأمر يحقق المصلحة العامـة، بحيث إذا أخطأت

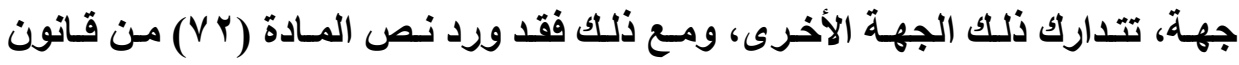

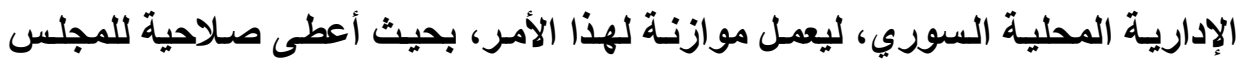

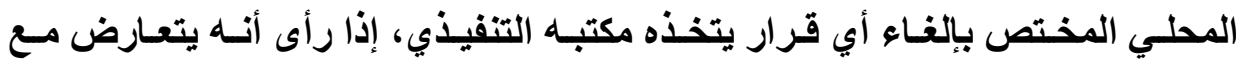
القوانين والأنظمة، أو مع خطة المجلس وبرامجه، فالمشرع هنـا قد أعطى صـلاحية

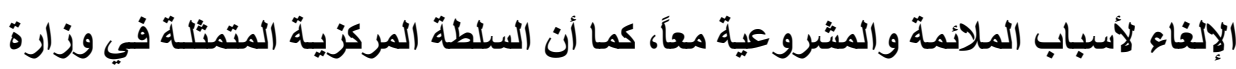
الإدارة المحلية، تتذخل بالتصديق على عقود الوحدات الإدارية المحلية إذا زادت قيمتها على مليون ليرة سورية. أما إذا تجاوزت عشرة ملايين ليرة سورية، وكانت من عقود الإنفاق الاستثماري، أو خمسة ملايين ليرة سورية، وكانت من عقود الإنفاق الجاري،

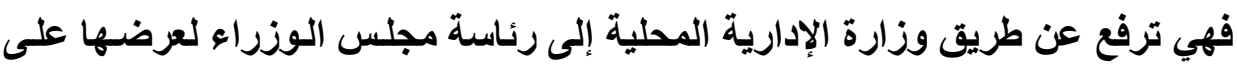
اللجنة الاقتصادية حسب الأسس المتبعة(؟).

مما تقام نجد بأن عقود الوحدات المحلية تحتاج إلى التصديق عليها من الإدارة

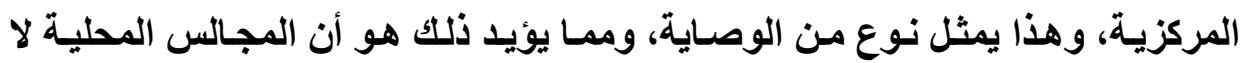

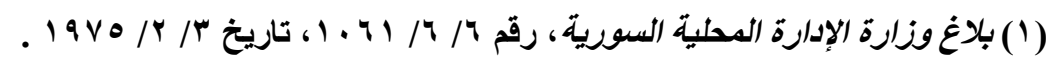

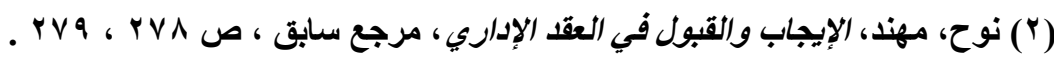


تستطيع مـنح قروض إلى الغير إلا بقـانون (')، وبالمقابـل لا تستطيع الحصول على قروض من مصادر أجنبية إلا بقانون().

\section{رابعًا: السلطة المختصة بإبرام عقود تفويض المرفق العام في الاردن:}

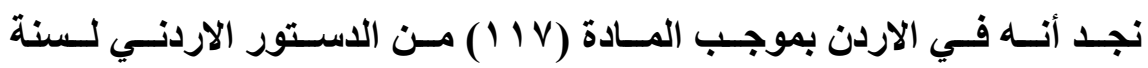

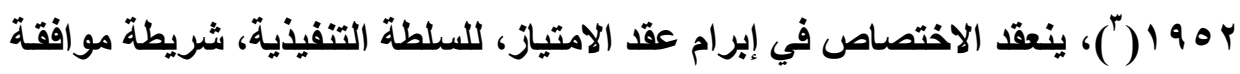
مجلس الامة، وذلك بالنسبة لعقود الامتياز المبرمة مع الثركات والمؤسسات الأجنبية، وكذلك الامر فان انشاء اي مرفق عام وطنية يتطلب اعتمـادات ماليـة لابـ من عرضهها على مجلس الامة لاعتمادها ، لان البرلمان حصرا يختص بهذا الجاتب، ويمثل السلطة التتفيذيه في هذا المقام مجلس الوزراء الذي يتخذ قراراتـة باعتباره صساحب الولايـة

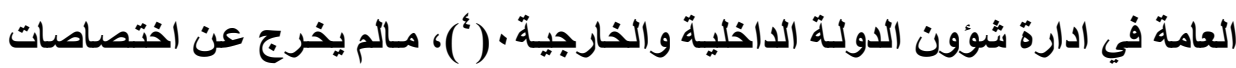
مجلس الوزراء اي امر بموجب نصوص الاستور او بموجب القوانين(م). وفيما يتعلق بالمرافق المحلية فانه من المعلوم ان عناصر اللامركزيـة الاقليمية هي: وجود مصالح منميزة عن المصالح الوطنية وان تدار هذه المصالح من قبل هيئات منتخبـة مـن اجل اشسباع حاجـات المـواطنين فانهـا الاقدر على تلمس تلكـ الحاجـات

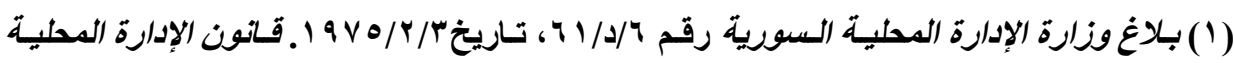

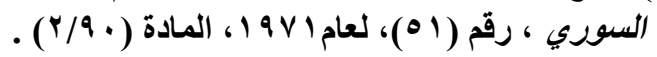

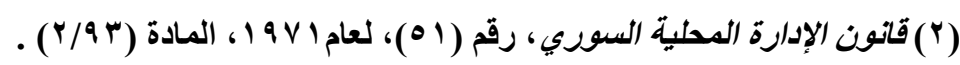

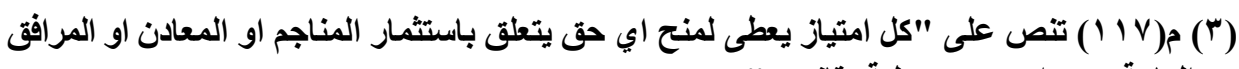

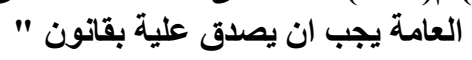

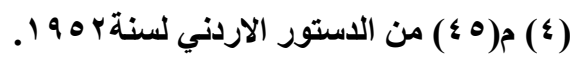

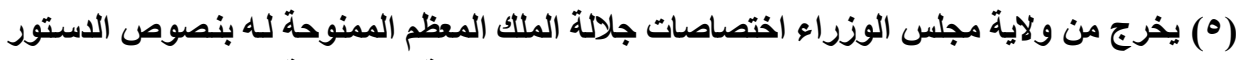

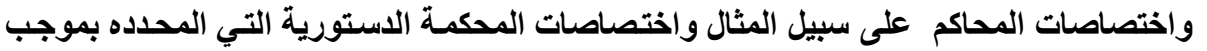
نصوص الاستور ويموجب قانون المحكمة الاستورية وغير هات 
واشباعها(') اي ان الادارة هي التي تتولى انشاء تلك المرافق وابرام تلك العقود،

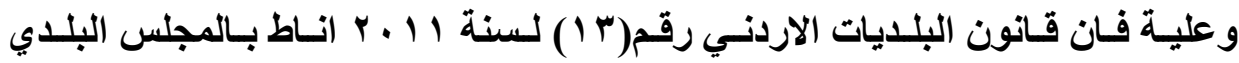
مجموعة من الصلاحيات والسلطات يمارسها ضمن الحدود الجغرافية للمجلس البلاي بواسطة موظفي البلايـة ومستخدميها او ان يعهل بها المجلس البلدي السى متعهد او ملتزم او مقاول او ان يططي بها او بيطها امتياز لاشخاص او شركات لمدة لاتتجاوز

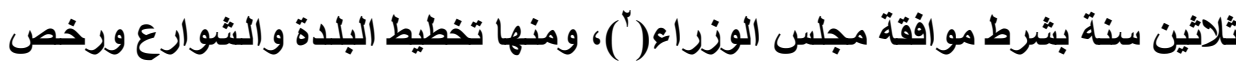
البناء و المجاري والاسواق العامة والحرف والصناعات ووسائط النقل البري والمحلات

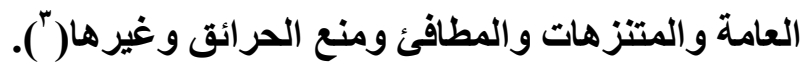
ونحن نتفق مع الرأي القائل بضرورة التمييز في تفويض المرافق العامـة بين

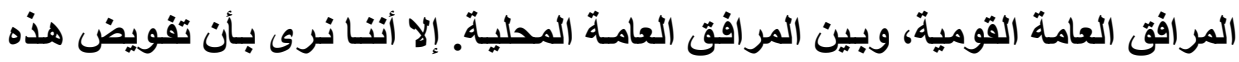

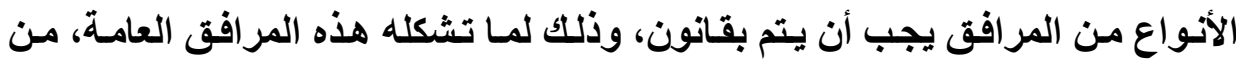

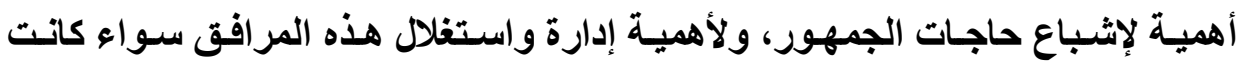
محلية أو قومية، ففي المرافق العامة القومية، يجب أن ينعقد الاختصاص في تفويضها

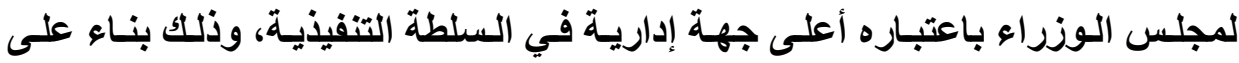

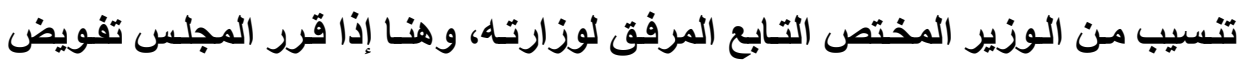
المرفق لابد له من الحصول على موافقة البرلمان قبل السماح بتفويض المرفق وتوقيع عقد مع الملتزم، وسندنا في ذلكت أن معظم الاسـاتير في العالم تنص على لعى أن تفويض المرافق العامة تحتاج إلى صدور قانون وموافقة البرلمان ، كما هو الحال في الدستور

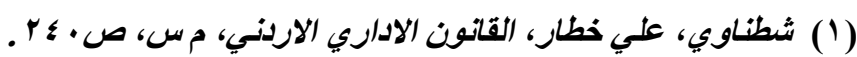

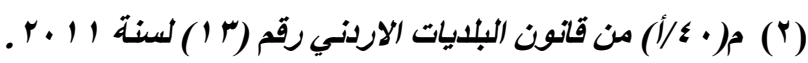

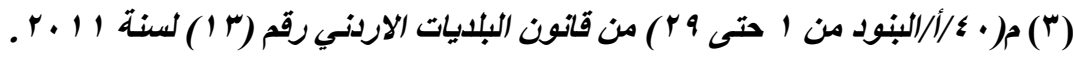

$$
\begin{aligned}
& \text { rOA مجلتً البحوث القانونيتوالإقتصاديت }
\end{aligned}
$$




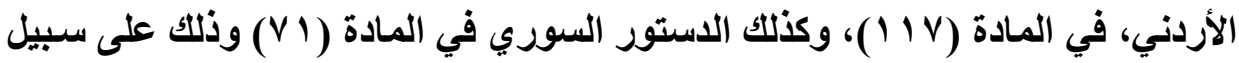

ضـافة إلى أن التفويض ربمـا يتم لمتعاقد أجنبي وليس محلي، كمـا أن هدف

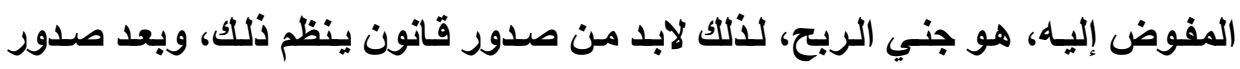
قـانون يـنم إجـراءات التفويض بالتفـصيل، يسمح للـوزير المختص بإصـار قـرار

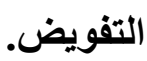

أمسا بالنسبة للمرافق العامـة المحليـة، فندن نرى ضـرورة صدور قـانون مـن البرلمان، بالمو (فقة على تفويضها، شريطة أن يكون الاختصاص في إبرام العقد، ينعقد

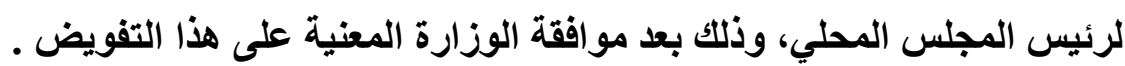

اي انــة نـرى بـأن التفويض في المرافق العامـة المحليـة أو المرافق العامـة القومية، لابد من صدور قانون ينظمه، مع ترك تقدير الحاجة للوزير المختص في عقود

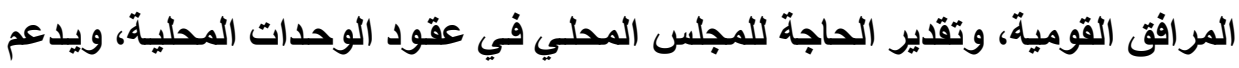

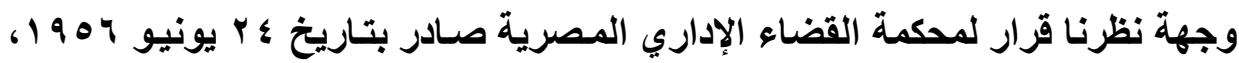
يؤيد ضرورة منح الالتزام بقانون(') فعندما تمارس السلطة التنفيذية صلاحياتها تحت الحت رقابة المشرع تصبح مضنة اهدار حقوق الافراد وحرياتهم ابعد مايمكن.

ويجدر الاشارة ان وسيلة تنظيم المرفق العام في الدول المقارنة تكون بقرارات

ادارية، وتملك الادارة سلطة تقديرية في ذلكك، ومن يملك الانشاء يملك الالغاء دونما

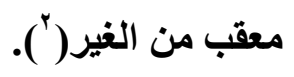

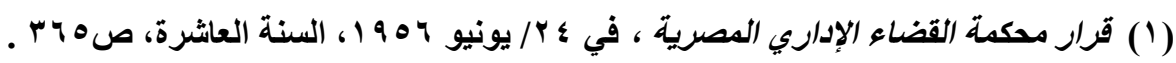

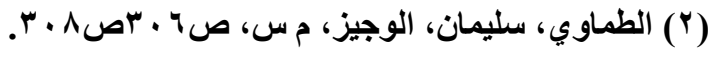
ro9 مجلة البحوث القانونيتوالإقتصاديت 


\section{المطلب الثاني: المشروع ذاته همل التفويض:}

في الغالب يكون المفوض إليه في عقود تفويض المرفق العام مشروع خاص، وينطبق ذلكت على الجمعيـات، وشـركات الاقتصاد المختلط ومسن الممكن أن يكون المفوض إليه شخصاً عاماً في أحوال استثنائية. ونتـاول هنا بحث الجمعيات وشركات التهات القطاع العام والخاص و الأثخاص العامـة كمفوض إليه، والتفويض الفرعي للمرفق العام( ')، وذلك على النحو التالي:

\section{الفرع الأول: الجمعيات الخيرية والهيئات الاجتهاعية:}

يقصد بالجمعيات ولهيئات التي لاتستهدف الريح وفقا للقانون النموذجي للجميات والهيئات المعد من قبل المركز الدولي لقانون المنظمـات غير الهادفة للربح: أي هيئة تمارس نثاطات تستهدف المنفعة العامة والمسجلة والمرخصة لتلك الغاية بحيث تثمل الانثطة غير الهادفة لتحقيق الريح او الانشطة ذات النفع العام اي نثاط مشروع يدعم

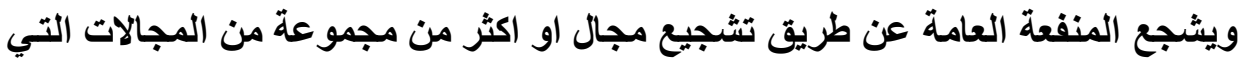

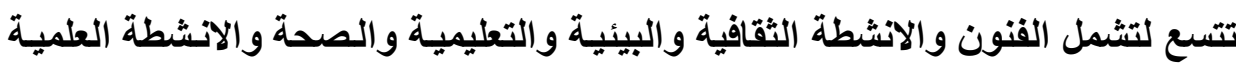
وغيرها من الانشطة التي تعترف لها الجهات المختصة بانها تساهم في دعم المنفعة

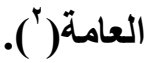

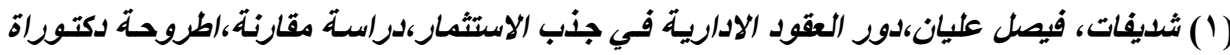

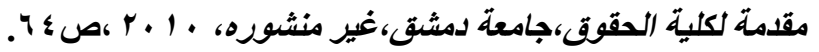

(2) International center for Not-for-profit law, Model provisions for laws Affecting public bennefit org, Washington DC, USA,2002,PP (1-2). Through: http://www.icnl.org/knowledge/pubs/law-PBO-English.pdf.

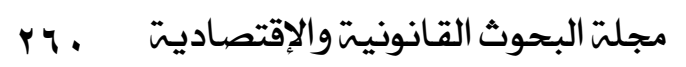


ولا تسعى الجمعيات الخاصة لاقتسام الربح، إلا أن هذا لا يعني إبعادها بثكل كلي عن دائرة النشـاط الاقتصادي، حيث تخضع للقواعد الخاصـة بمساعدة المشروعات (')(Association of Projects)

ويجوز لها أن تمارس نشاط اقتصادي، وفي هذا الثأن قرر المجلس الاستوري

الفرنسي: 》أن المبدأ الاستوري بشأن حرية الجمعيات لا يمنع الجمعيات من أن تحصل الإيرادات الضرورية لتحقيق أهدافها، والتي ليست اقتسام الربح بين أعضائها بواسطة ممارسة أنشطة ربحيةه) ().

ودخلت الجمعيات عـالم المشروعات، وهذا يتفق مـع القانون الأوروبي بشكل

خاص، والذي يعتنق مفهومـاً واسعاً للمشروع، إذ يعتبر أن كون الشخص المعنوي لا يستهدف غرضاً مالياً، لا يرفع عن النشاط الذي يمارسه الطبيعة الاقتصادية("). وهنالك العديد من الجمعيات في فرنسا تتولى إدارة مرافق عامـة، وحينئذ تعتبر مشروعات خاصـة لمرافق عامسة ،حتى ولو قامت بإدارة مرفق عـام ليس من طبيعة صناعية وتجارية، وهذه الجمعيات وإن كانت خاضعة لقانون الجمعيات الصادر في عام 1 19 1 ، إلا أنها جمعيات أنشأها في الغالب شخص عـام للقيام بمهمـة محددة. وبالتـالي

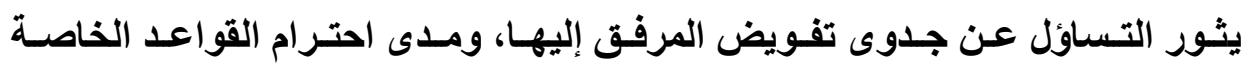

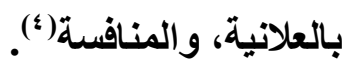

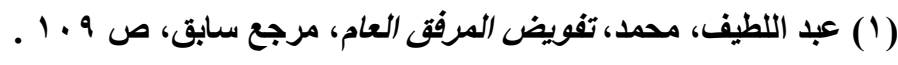

(2) C.C., 25 juillet 1984, N. 176 DC, Rec., p. 55.

(3) L. Richer, precite, Remargues sur les enterprises de service public, AJDA, 1997. p. 204.

(4) D. Giltard, L'association de La Loi de 1901 et Le spic' Jcp, 1981, L, 3028.

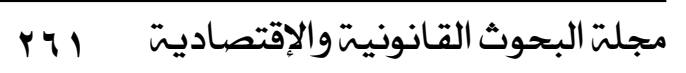




\section{الفرع الثاني: شركات القطاع العام والخاص:}

يكون الطرف الاخر في عقود تفويض المرفق العام احد اشخاص القانون الخاص

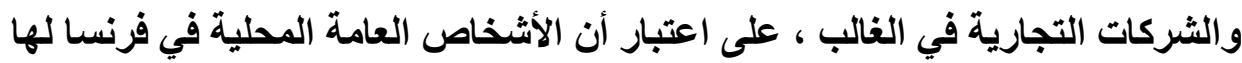

$$
\text { أغلبية رأس المال في الثركات(') }
$$

أما شركات الاقتصاد المختلط التابعة للاولة، فهي ليست بالضرورة مشروعات

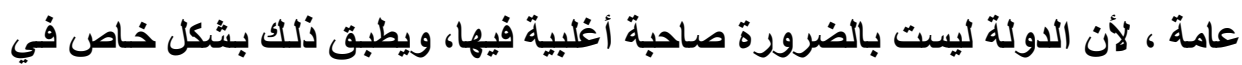

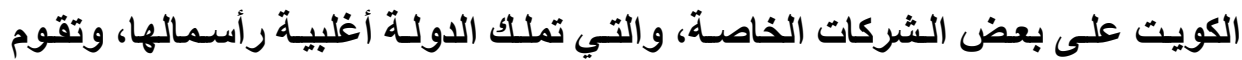
بتفويضها باستغلال بعض المرافق، كشركة المشروعات السياحية التي تعهد إليها

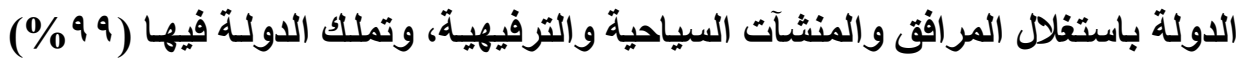

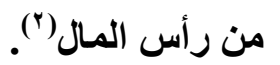

وفي مصر ينطبق ذلكت على شركات قطاع الأعمـال العسام، لأن هذه الشركات

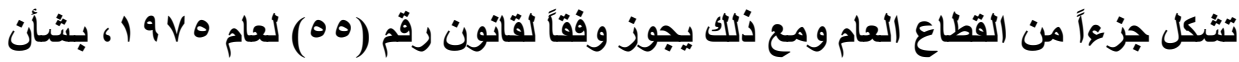

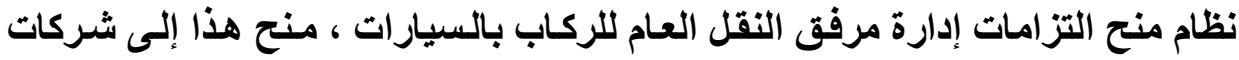

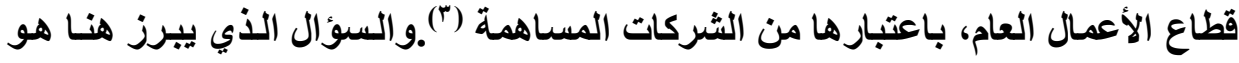

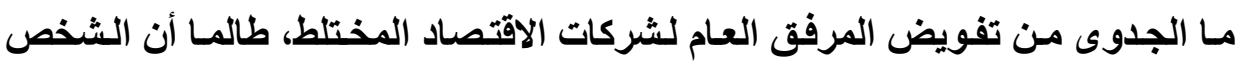

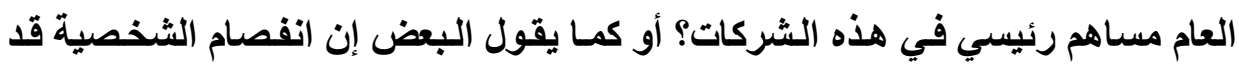

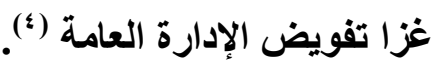

(1) C.E., avis, section de I' Interieur lonov, 1993, rapp, n. 45, p. 49.

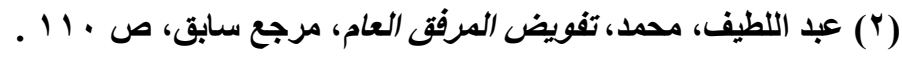

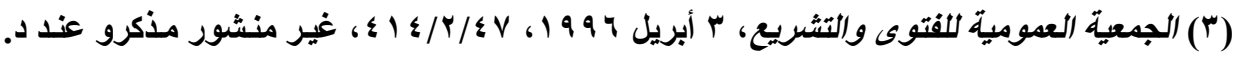

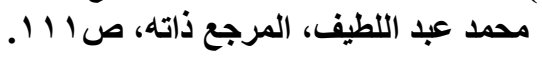

(4) Ph. Limouzin - Lamothe, La partigue de La delegation de service public, A J D A, 1996, P. 575 . 
ويجوز التفويض لأشخاص طبيعيين أياً كانت جنسيتهم مواطنين أو أجاتب ، وقد قررت ذلك بشكل صريح القوانين الصادرة في مصر والمتعلقة بالتزامـات المطارات،

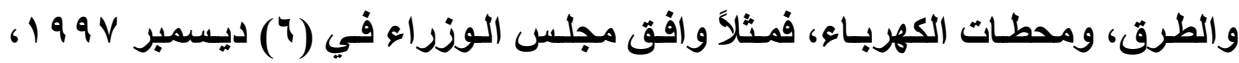

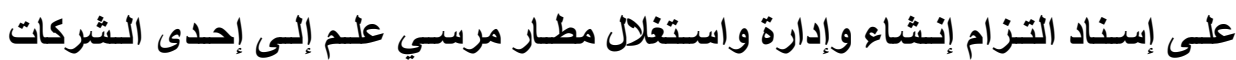
(الكويتية) (1) (1)

ونحن نرى أن الجدوى في تفويض المرفق العام في مثل هذه الحالة لشركات الاقتصاد المختلط، فيه تحقيق مصلحة الإدارة في حسن إدارة المرفق وحسن استغلاله على الوجه الأمثل وتطبيق قواعد العقود الخاصـة عليه، وهذا مـا حصل في الأردن في تفويض شركة الاتصالات إلى شركة فرنسية، مع بقاء الحكومة تملك نسبة من الأسهم في رأس مال الشركة.

\section{الفرع الثالث: الأشخاص العاهمة:}

فالمؤسسات العامة على اختلاف أنواعها تقوم على إدارة مرافق عامة مشخصة،

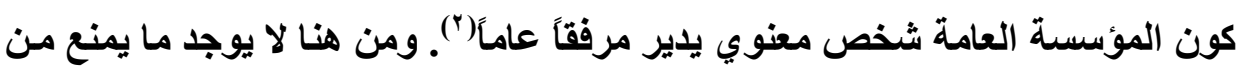
أن يتم التفويض لأشخاص عامة كالمؤسسات العامة (Public institutions). ومن أبرز التطبيقات في فرنسا التزام توزيع الغاز، والكهرباء، والذي عهد إلى

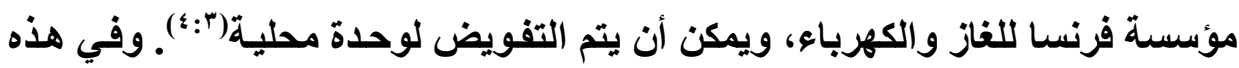
العـالات فـلا يطبـق مـن حيـث المبــأ قـانون (Sapin) وخـصوصاً، المــادة (1 ؛ ).

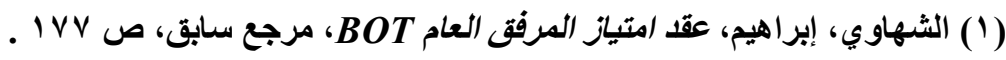

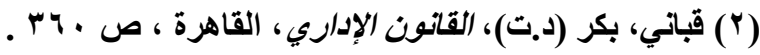

(3)Ph. Terheyre, La nation de conversation de delegation, precite, p. 590.

(4)P. delvolve, Les contradiction de La delegation de service public, A J D A, 1996, p. 687 . 
والتفويض في مثل هذه الحالات غير مفهوم. فمن ناحية إذا كان الهـف من التفويض مساهمة القطاع الخاص في تحقيق المرونة في إدارة المرفق، فإن هذا الأمر يتحقق إذا لإنا كان التفويض إلى شخص عام أيا كان نظامه القانوني، ومن ناحية أخرى فإن التفويض التران

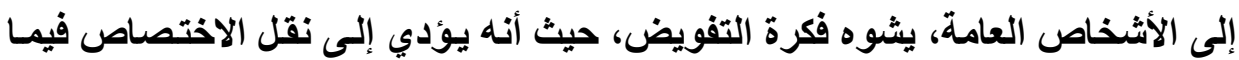

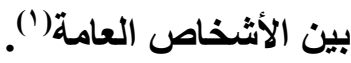

وفي مصر فإن منح التزامات البحث عن البترول واستغلاله تتم بقانون(؟) ونحن نرى بأنسه لوضوح فكرة التفويض يجب أن يتم التفويض إلى القطاع

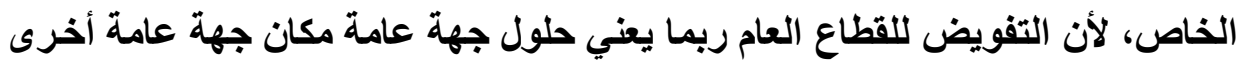
في استغلال المرفق، وبالتالي لا تتحقق المرونة في الإدارة. الفرع الرابع: التفويض الفرعي اللمرفق العام:

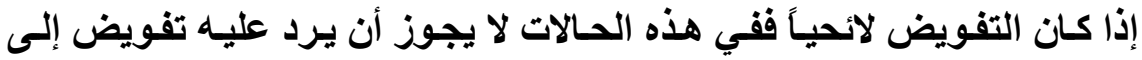

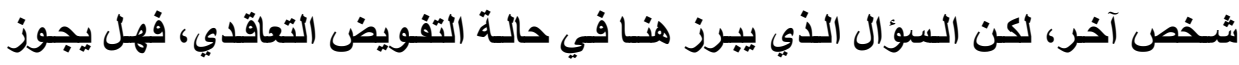

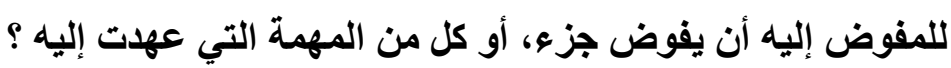

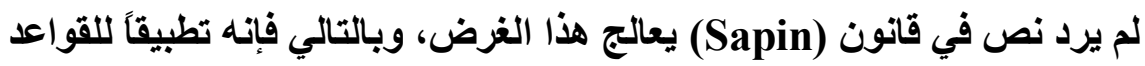

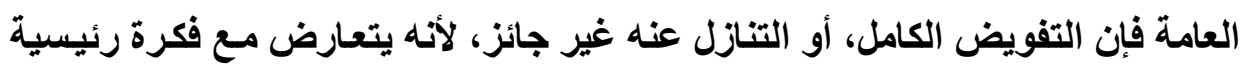

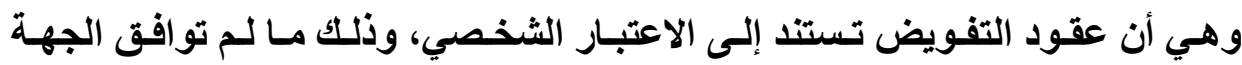
الإدارية على هذا النزول("). أما إذا تتازلت الجمعية المتعاقدة مع الإدارة دون مو افقتها،

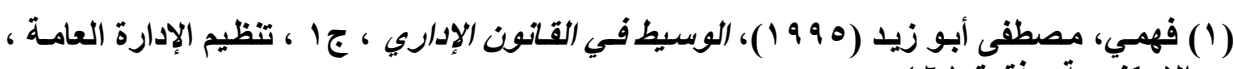

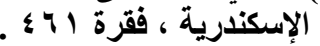

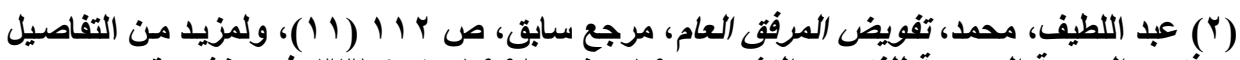

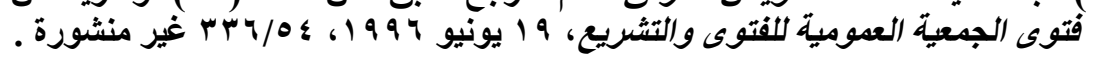

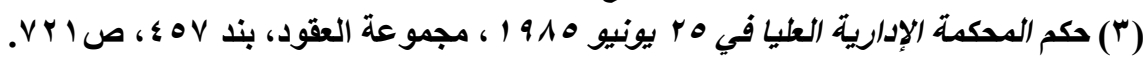

- Ph. Limozin - Lamothe, La pratigue de La delegation de service public, precite, P. 575 .

مجلت البحوث القانونيت والإقتصاديت ؟ ب 
فإنه لا يحتج بهذا التنازل في مواجهة الإدارة، ولا تنشأ أية علاقة تعاقدية بينها وبين المقاول من الباطن، بل تبقى الجمعية مسؤولة وحدها قبل الإدارة(') وفي كثير من الحالات العملية فإن المفوض إليه ليس هو القائم بالتشغيل ، حيث

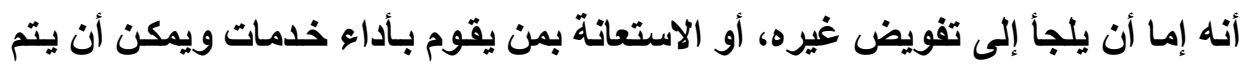

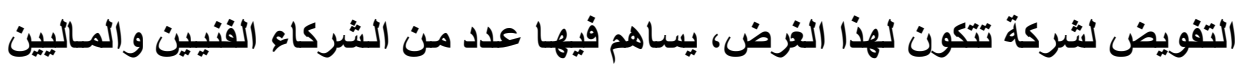

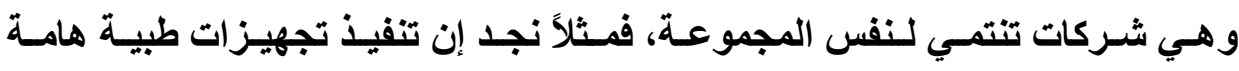

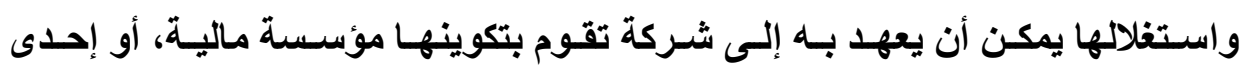

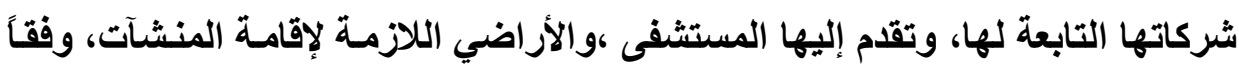

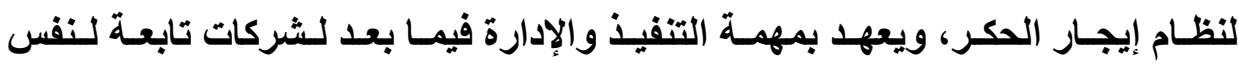

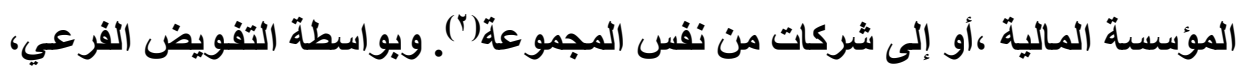

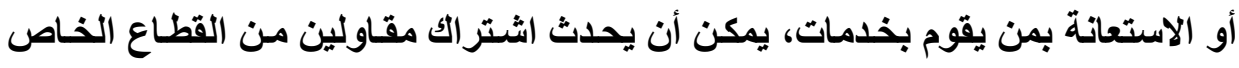

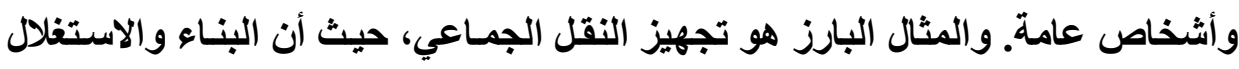

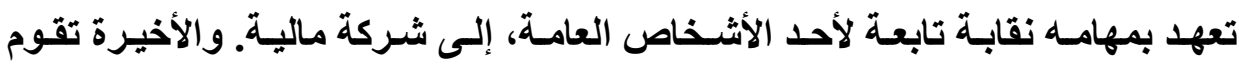

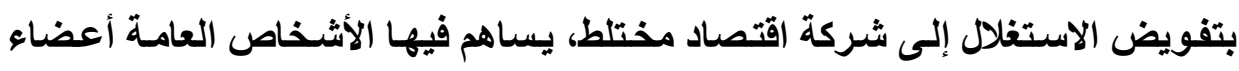

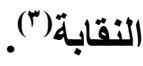

والتطبيق الحديث لهذه الفكرة في مصر في التزام إنشاءات واستغلال مطار

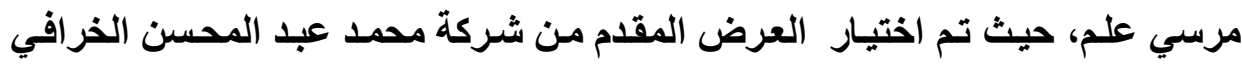

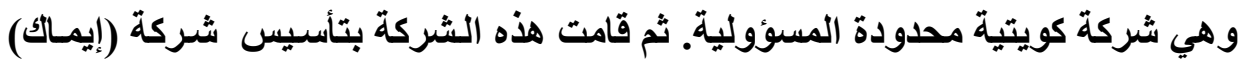

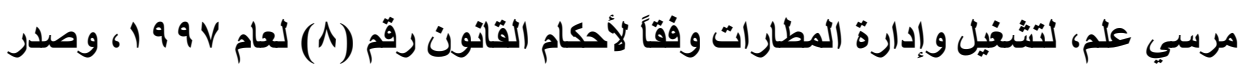

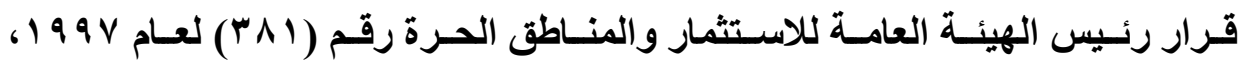
بالترخيص بتأسيس هذه الثركة، وهنا رأى مجلس الدولة أن يتم إبرام عقد ثلاثي بين 


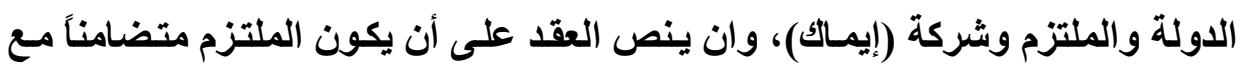

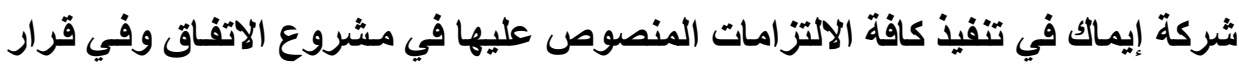

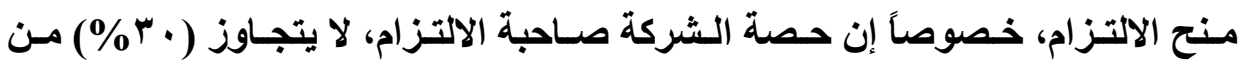

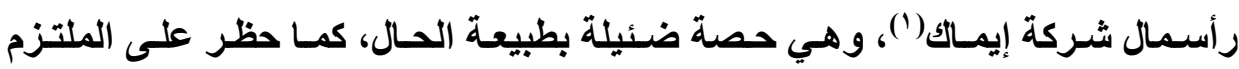

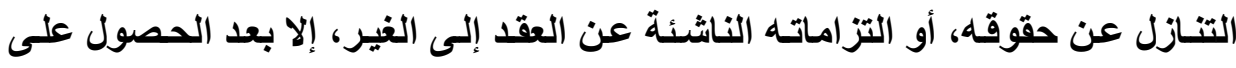

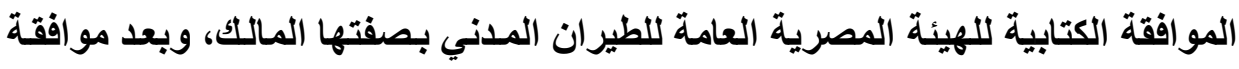

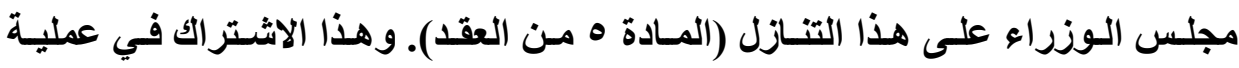

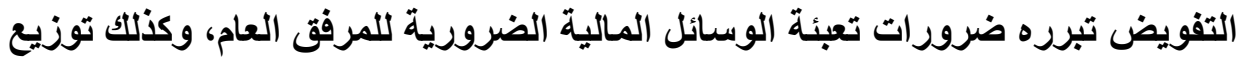

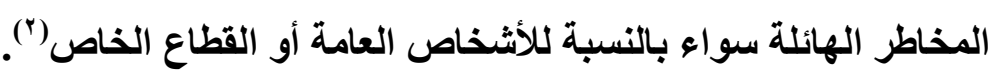

ونحن نؤيد التفويض الفرعي للمرفق العام، شريطة أن يكون ذلكت المرفق قابلاً

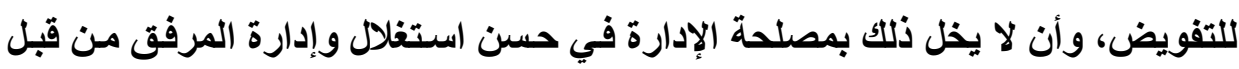

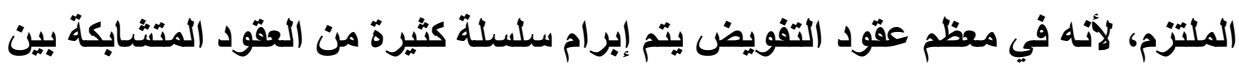

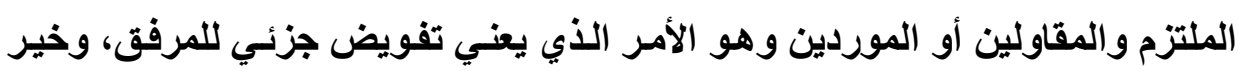

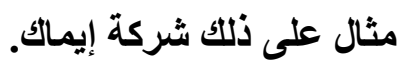

$$
\text { (1) عبد اللطيف، محمد محمد، تفويض المرفق العام، مرجع سابق، صV9 }
$$

(2) C.E., 20 juillet 1990, ville de me lun, AJDA, 1990, p. 820, conc IM pochard: D. 1991, P. 578, note G vlacho; Jcp, 1991, n. 21663, note E. fatome.

مجلت البحوث القانونيت والإقتصاديت ب r ب 


\section{المبحث الثاني \\ المستفيدون هن المرفق العام}

وهم الأشخاص الذين يستظون المنشآت العامـة، أو هم الذين ينتفعون بالمرفق

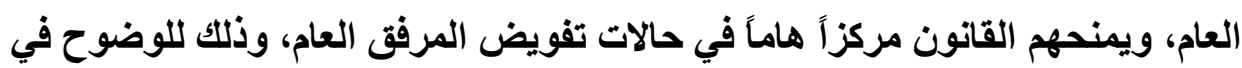

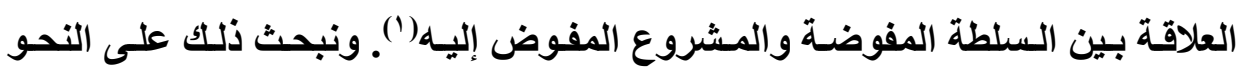

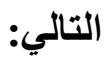

المطلب الأول: حقوق المستفيدين وطعونهم في هجال تفويض المرفق العام: يتمتع المستفيدون من خدمات المرفق العام بعدة حقوق كما أن لهم الحق في

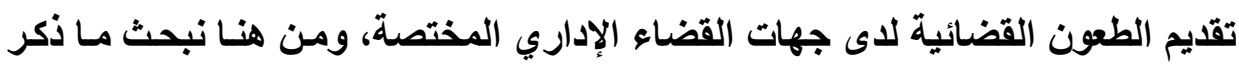

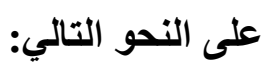

\section{الفرع الأول: حقوق المستفيدين في هجال تفويض المرانق العاهة:}

يتمتع المستفيدين من خدمات المرفق العام بعدة حقوق لعل من أهمها:

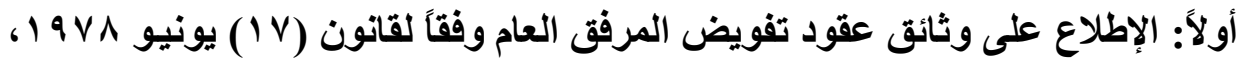

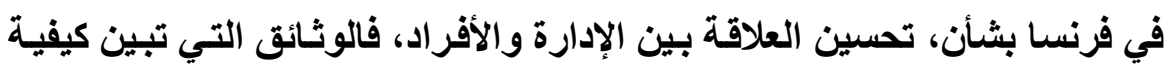

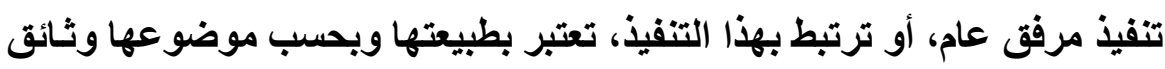

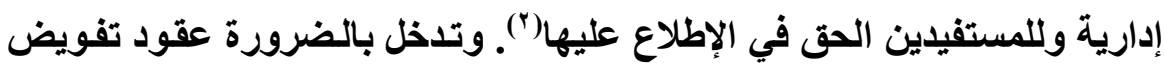

(1) P. prades, Les relations entre Le delegation et Le delegataire, AJDA, 1996, P. 640.

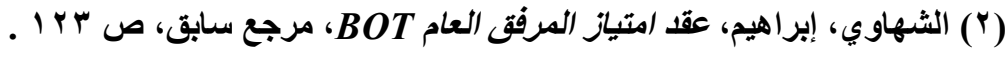

مجلتة البحوث القانونيت والإقتصاديت 
المرفق العام في هذه الطائفة من الوثنائق الإداريـة التي يجوز الإطلاع عليها،

باستثناء الشروط التي يغطيها السر التجاري(').

ثنانياً: يجب أن تحدد عقود تفويض المرفق العام، التعرفة التي يتحملها المستفيدون،

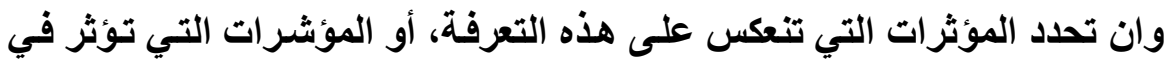

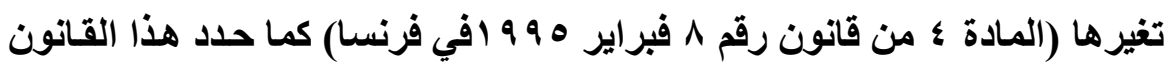

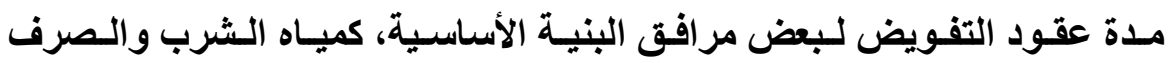
الصحي، ومرافق النفايات لمدة لا تتجاوز عشرين عامًاً(").

ثُالثاً: المساهمة في الرقابة على عقود تفويض المرفق العام، ومظاهر الرقابة التي يمارسها المستفيدون من المرفق العام في مجال التفويض تبدو فيما يلي("):

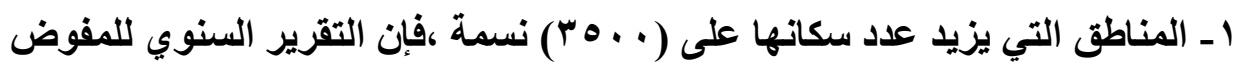

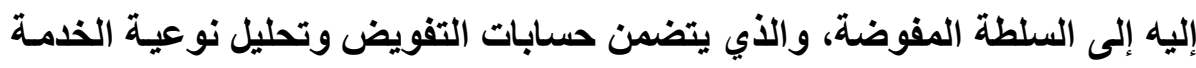

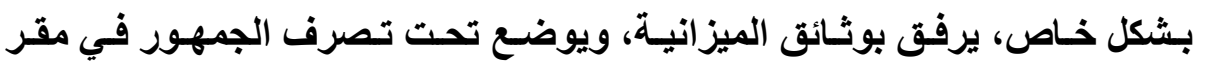

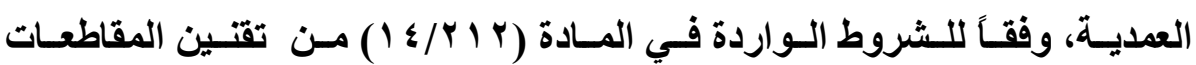

$$
\text { الفرنسي. }
$$

r - يجب أن يوضع تحت تصرف الجمهور التقرير السنوي للسلطة التنفيذية للشخص

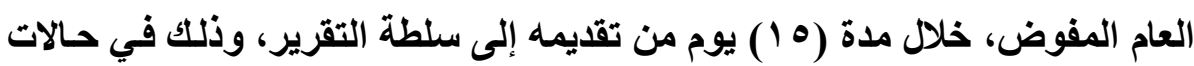

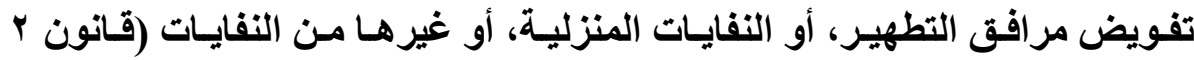

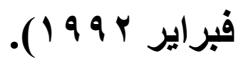

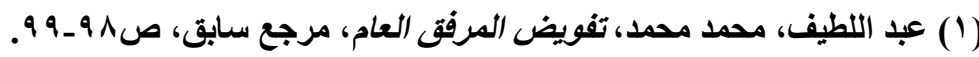
(2) C,E, juin 1989, Association Etudes et consommabion CFDT, Aec, p, 544.

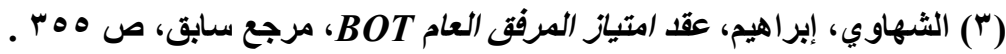




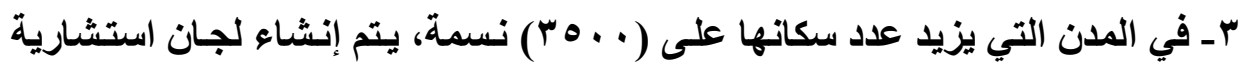
فيها، ويجب أن تضم ممثلين عن جمعيات المستفيدين من المرافق العامـة التي تدار

$$
\text { بأسلوب التفويض. }
$$

\section{الفرع الثاني: طعون المستفيدين في هجال تفويض المرفق العام:}

يحق للمستفيدين العلم في القرارات الإدارية المتعلقة بتظظيم وتسيير المرفق

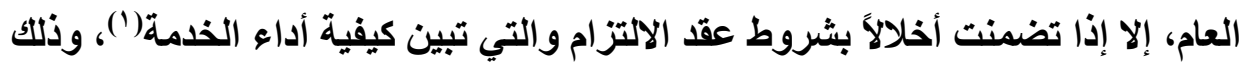

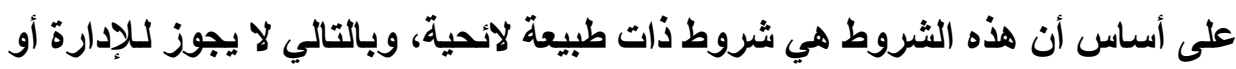

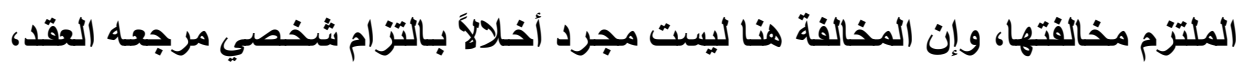
بل هي مخالفة لقاعدة لائحية تضمنها العقد ("). وهذه الحمايـة مقررة للمستفيدين سواء كانت المرافق إداريـه أو صناعية أو

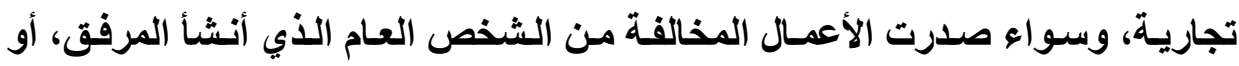
المشروع الذي عهـ إليه تنفيذ المرفق("). وهنا هل يجوز للمستفيدين الطعن في شروط العقد نفسه؟ جواب هذا السؤال يتطلب التمييز بين الثروط اللانحية والثروط التعاقدية.

فالشروط اللائحيـة الواردة في عقد التفويض، يجوز للمستفيدين الطعن فيها

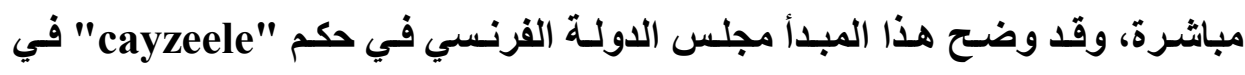

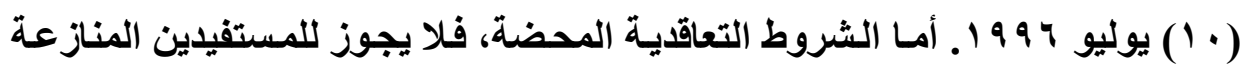

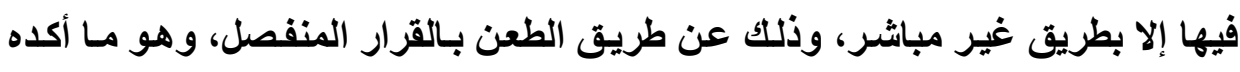

(1) C,E, juin 1989, Association Etudes et consommabion CFDT, Aec, p, 544.

(2) C.E., 4 aout 1905 , mavtir, Rec, p. 749 , concl, Aomieu; s. 1956 III, p, 49.

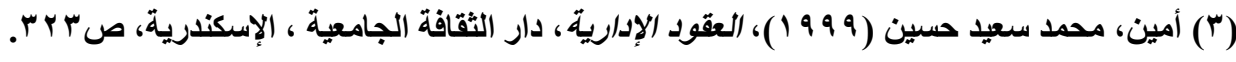

مجلم البحوث القانونيت والإقتصاديت 
مجلس الدولة الفرنسي منذ حكم "martin" في ه ـ 9 ("). بينما يرى جانب من الفقه الفرنسي بأنه لا يمكن الاستناد إلى شروط عقد من العقود توصلًا إلى إلغاء قرار إداري

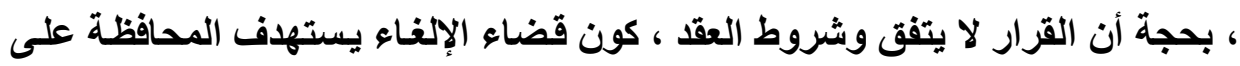
قواعد المشروعية على عكس العقود التي تولد التزامـات شخصية يؤدي الإخلال بها إلى إثارة القضاء الكامل(")

ومعيار التمييز بين الثروط اللائحية والشروط التعاقدية يستند إلى أن الشروط اللائحية، هي تلكك النصوص الواردة في كراسـة الشروط، ويمكن أن توجد مرة أخرى في لائحة استغلال المرفق، إذا ما تم إدارته بالاستغلال المباشر، بينما الثروط التعاقدية هي تلكك النصوص التي لا يتصور وجودها في نظام الاستغلال المباشر، لأنـه لن يكون

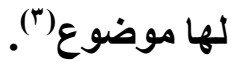

وبالتـالي فالشروط الخاصـة بتنظيم أو تشغيل المرفق هـي شروط لاتحيـة، أمسا الثروط المالية الخاصة بالمزايا المالية وغيرها من المزايا التي يحصل عليها الملتزم من السلطة ماتحة الالتزام ، فإنها من الشروط التعاقديـة، كونها لا تهم الجمهور ولا تتعلق بتنظيم المرفق، إلا أن الطبيعة التعاقدية تتعلق فقط بالثروط التي تتناول العلاقات المالية بين المتعاقدين. كمـا أن الفقه يرى بـأن الشروط الخاصـة بالمقابل المسالي الذي يحصل عليه الملتزم من المستفيدين تعتبر جزءاً من الشروط اللانحيـة، كونها تمثل

(1)A .de Laubadere, F. moderne, p. Delvolve; Traitedes contrats administrative, L.G.D.J, T.1, 1983, n.70.

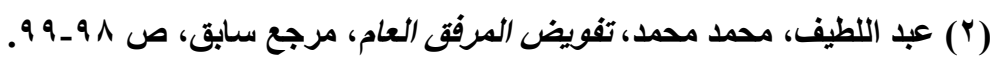

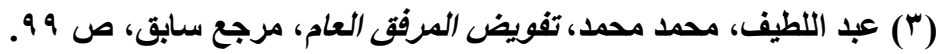

rv. مجلت البحوث القانونيت والإقتصاديت 
عنصراً أسساسًا في تسيير المرفق، وتهم مباشرة المستفيدين من المرفق، و القضاء الفرنسي اعتنق مؤخرا هذا التكييف(').

غيـر أن مجلس الدولـة الفرنسـي أصسدر مـؤخراً حكمساً، قرر فيـه تـوافر شـرط المصلحة في دعوى للمستفيدين مـن مرفق الطريـق السريعة للطعن في القرارات الصادرة باعتمـاد الاتفـات المبرم بين الدولـة وبعض شركات التزام الطريق السريعة، وهذا الاتفـاق يتضمن نصاً مفـاده التزام الملتزم بـأن يدفع للاولـة مبلفـاً مالياً، مقابل تكاليف تثغيل قوات الثرطة المكلقة بالخدمة في هذه الطرق، ومقابل تكاليف الرقابـة التي تمارسها الدولة على منشآت هذه الطرق(). واضح أن الشروط الخاصة بتكاليف تشغيل قوات الشرطة، وتكـاليف الرقابة لا تتعلق بـصورة مباشـرة بتحديـــ التعرفـة، إلا أنهـا تـنعكس بـشكل غيـر مباشـر على المستفيدين، ومن شأن تطبيق القواعد العامة، فِان هذه الشروط تعتبر شروطاً تعاقدية، كونها تتعلق بالعلاقات المالية بين الدولة والملتزم، وبالتـالي لا يجوز الطعن فيها من جانب المستفيدين، ومع ذلك كان من الممكن أن يطور مجلس الدولة الفرنسي قضاءه، في حكم (cayzeele)) ويسمح بقبول دعوى الإلغناء ضد النصوص غير اللائحية)(")، إلا أن الجمعية العمومية لمجلس الدولة، لم تكن مستعدة للوصول إلى هذه النتيجة بهذه السرعة، رغم انتقاد الفقه لمسألة التمييز في منازعات العقود بين النصوص اللائحية والنـصوص التعاقديـة، ومـع ذلــك يـرى البعض أن إمكانيـة قبـول الطعـن مسن جانـب

(1) عبد اللطيف، محمد محمد، تفويض المرفق العام، مرجع سابق، ص 99 . (2) D, chauvaux, Girardot (T.X.), chronigue generale de jurisprudence administvative fran- caise, AJDA, 1996.p,973 cts.

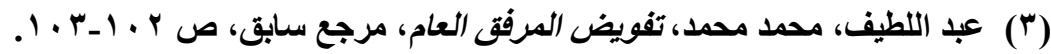

PVI مجلت البحوث القانونيتوالإقتصاديت 
المستفيدين من المرفق في النصوص التعاقية للالتزام هي مسألة وقت، وذلكك يعني إعادة النظر في معايير المصلحة في الدعوى"(') ونحن من جانبنا نرى بأنه يجب السماح للمستفيدين من خدمات المرفق الطعن

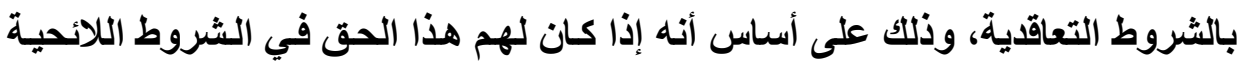
و الموضوعة بشكل مسبق في دفاتر الثروطو اللوائح، والتي تعتبر بهذه الصفة بمثابة

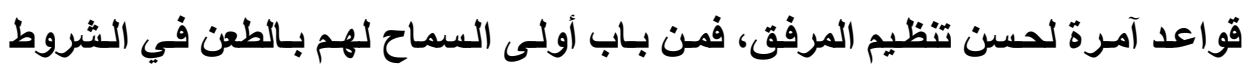

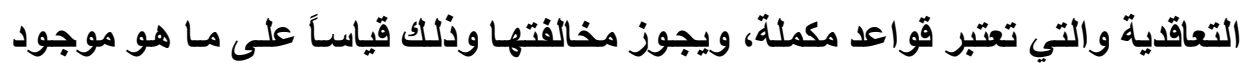
في القانون الخاص، ورغم أن العقود الإدارية تتميز عن عقود القانون الخاص، إلا أنتا

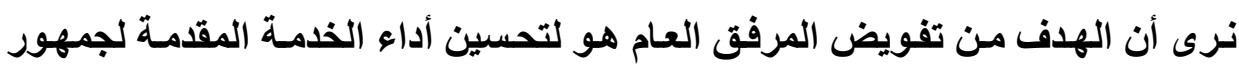

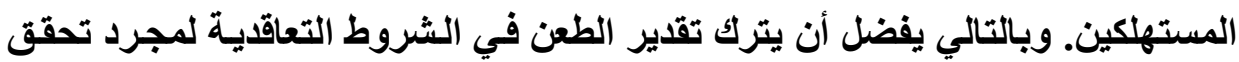

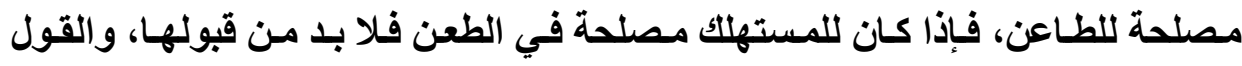

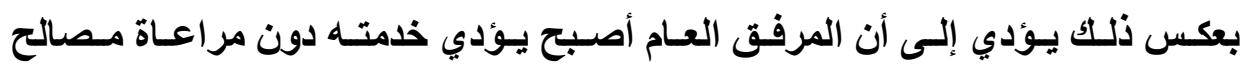

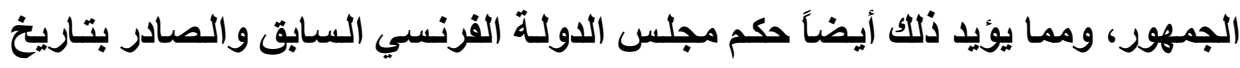

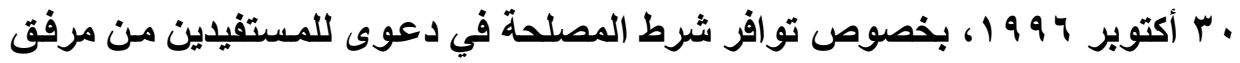

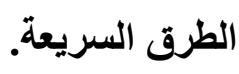

المطالب الثاني: المستفيدون بين قانون الاستهلاك وقانون المرافق العاهة : يحتل المستقيد من خذمات المرفق العام مرتبطة متوسطة بين قانون الاستهلاك وقانون المرافق العامـة، وذلك لأهمية الخدمات التي يقدمها المرفق العـام للجمهور

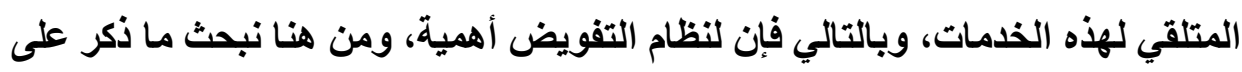

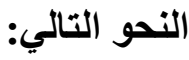

(1) الثهاوي، إبراهيم، عقد امتياز المرفق العام BOT، مرجع سابق، ص ^1 11 وما بعدها . rVY مجلت البحوث القانونيت والإقتصاديت 


\section{الفرع الأول: المستفيدون بين قانون الاستهلاك وقانون المرافق العاهة:}

يطلـق فـي بعـض الأحيسان على المستفيدين مسن المرفـق العـام اصــلاح

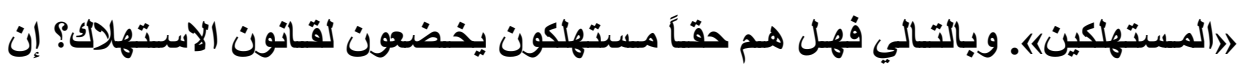
المستهلك هو من يستهلك خدمة، أو يستهلك سلعة قام مشروع بإنتاجها بقصد بيعها.

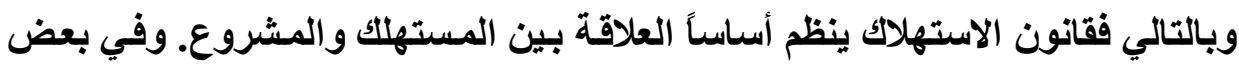

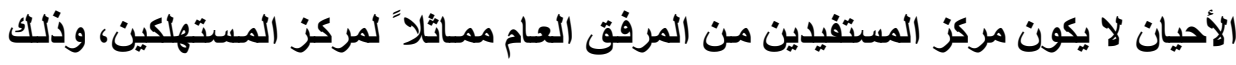
حين لا يوجد أداء محدد يمكن استعماله أو استهلاكه، كالمحافظة على الأمن. كما أنه قد الد

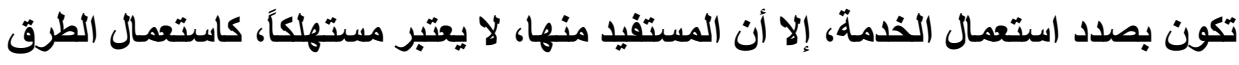

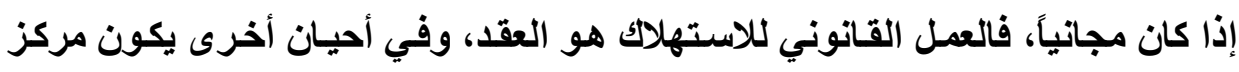
المستقيدين مسن المرفق العـام ممساثلاً لمركز المستهلك، وذلكت حين يستهلك أمسوال

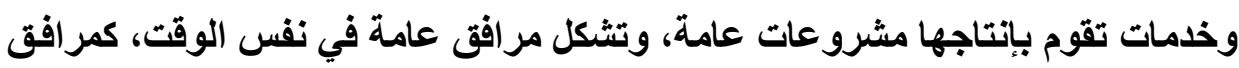

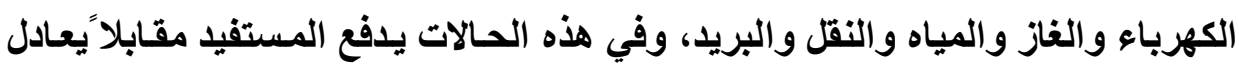

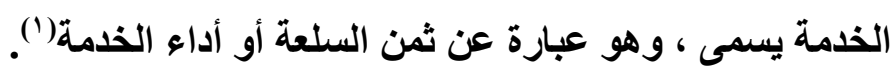
وقانون المرافق العامة يوفر حماية للمستفيدين ومن مظاهر الحماية، المبادئ

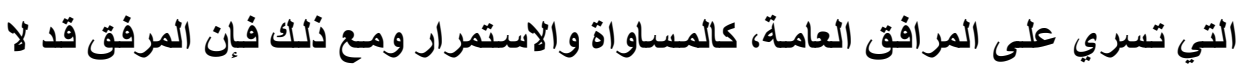

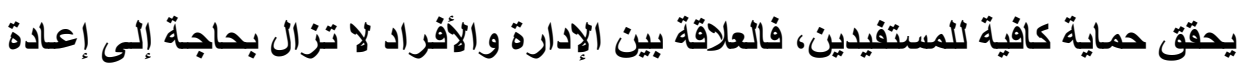
نظر، فالإدارة تسودها نزعة السيطرة، ولانرى في المستفسيدين من المرفق إلا مجرد

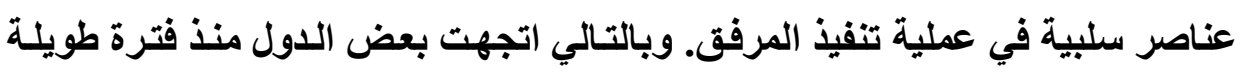

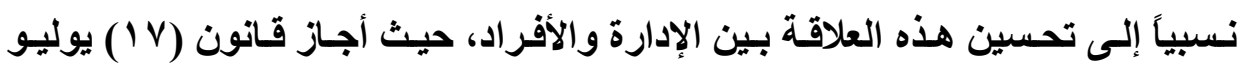
19 \ 1 ، في فرنسا تمكين المستفيدين من الاطلاع على عقود تفويض المرفق العام، كما

(1) عبد اللطيف، محمد محمد، تفويض المرفق العام، مرجع سابق، ص ؛ ـ 1. مجلت البحوث القانونيت والإقتصاديت rVr 
أن مبدأ قابلية المرفق للتعديل يمكن أن يؤدي إلى الأضرار بالمستفيدين، فقد يؤدي إلى نقص الأداء ، مثال ذلك إلغاء بعض خطوط السكت الحديدية'(1).

والمركز اللائحي للمستفيا يمنعه من التفـاوض حول شروط التعاقد، ويمكن أن يؤدي إلى إخضاعه لشروط تعسفية. فالعلاقـة بين المستفيدين والمرفق تتسم بعدم التوازن بين حقوق والتزامـات الأطراف في العقد، ويتضح ذلتك في العقود الخاصـة باثـتراك الكهربـاء والغـاز والميـاه(")". وحمايـة المستهلكين تأخذ صورا مختلفة وفقـا لقـانون الاسـتهلك، كــق المستهلكين فـي معرفـة خـصائص المنتجـات والخــمات، وحمايتهم ضد عيوب ومخاطر الخدمات والمنتجات، وحق الحصول على المعلومات عن الأسعار، وحمايتهم من الدعايـة الكاذبة، والاستعانة بجمعيات المستهلكين للافاع عن مصالحهم المشتركة أمسام القضاء وغيرهـا، وليس هنالكك مـا يمنـع مـن تطبيق قـانون الاستهلاك على المستفيدين من المرافق العامـة، خصوصاً أن المرافق العامـة أصبحت تتجـه إلـى تطبيـق قواعد القـانون الخـاص، كونهـا أخــت تقوم بـنفس الوظـائف مثتل المشروعات الخاصة تماما، إضافة إلى أن حماية المستهلك هي هدف يتعلق بالمصلحة العامة، بل إنها تعتبر مرفقا عامـا؟َ) الفرع الثاني: موققنا من حماية المستهلكين وقانون المرافق العامة: نحن نتقق مع نظام التفويض للمرافق العامة، حيث يحقق مصلحة للإدارة في حسن استغلال وإدارة المرفق على الوجه الأكمل، لكنتا نؤكد على ضرورة وجود هيئة تسمى هيئة تفويض المرافق العامـة سـواء كاتـت محليـة أو قوميـة، ويكون في هذه الهيئة عدد مـن

(1) T.C., 19 Ferrier, 1990, Espicc. C. / Institut national de la consommation, AJDA, 1990, P. 468, cancl Stirn .

(2) T.C., 19 Ferrier, 1990, Espicc. C. / Institut national de la consommation, AJDA, 1990, P. 469, cancl Stirn . 
الاختصاصيين الماليين والقانونيين والفنيين، والخبراء العالملين في مختلف المرافق المراد تفويضها، بحيث لا تقلم الدولة على التفويض لمرفق ما إلا بعد أخذ رأي هذه الهيئة، وحتى لفئي

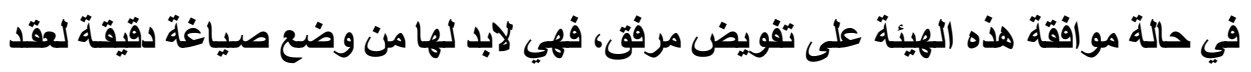

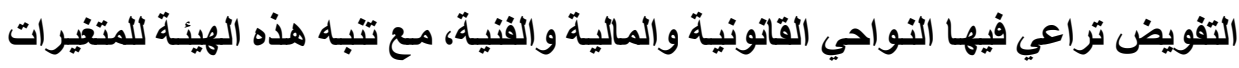
المستقبلية، بحيث يتم صباغة العقد لفترة زمنيـة قصيرة ، بحيث تستطيع هذه الهيئة

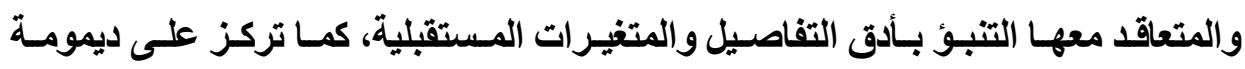
استمرار تأديـة المرفق للخدمات المطلوبـة منـه طبقاً لمعايير الجودة العالميـة، وبهذا يتت

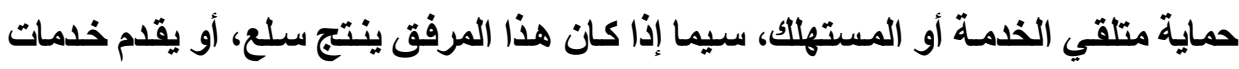

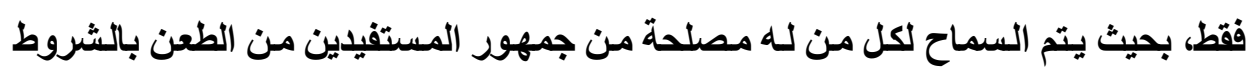
اللاحية أو التعاقدية، لأن مصلحة الجمهور هي مصلحة عامة، وبالتالي فهي تظلب على التى

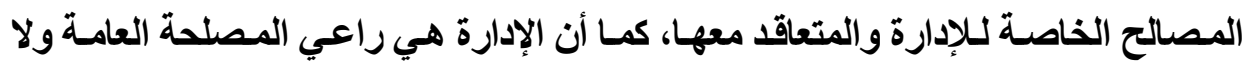

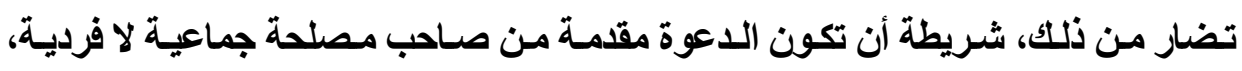

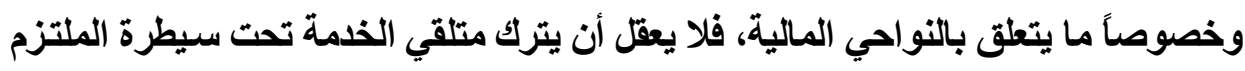

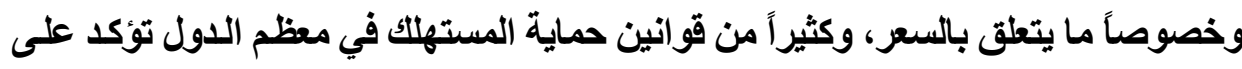

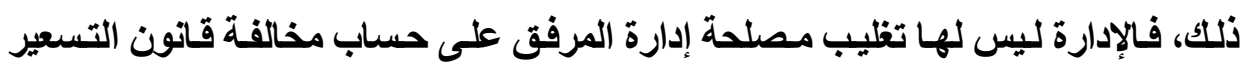

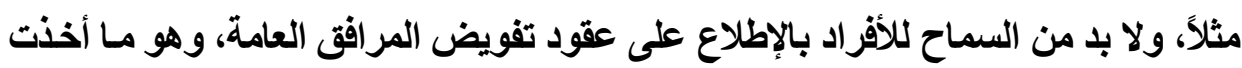

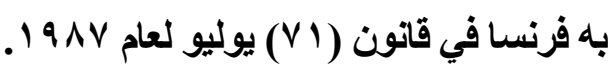




\section{خاتمة البمث}

لقد تناول الباحث التظيم الاستوري والقانوني للمراكز القانونية لاطراف عقود تفويض المرفق العام والمستقيدين منها ، من خلال بيان الحماية الدستورية والقانونية لاطر اف عقد تفويض المرافق العامـة والمستفيدين منـه وبيـان التزامـاتهم في مواجهة الادارة صاحبة السلطة والنفوذ. وتبين من خلال هذة الدراسة بعض النتائج نورد أهمها والتوصيات التي يراها الباحث وهي:

\section{أولاً: النتـائجه:}

ا - إن عقود تفويض المرفق العام عبارة عن عقود اداريـة قابلـة للتفويض من اجل اشباع حاجـات الافراد العمـة والضرورية، لا توجد الا بوجود أطراف رئيسة لها

$$
\text { ومستفيدين. }
$$

r - تثمثل عادة أطراف عقود التفويض بالسلطة المفوضـة، كمـا أن هنالك المشروع والمفوض إليه كأطراف في هذا النوع من العقود.

r- إن عقود تفويض المرفق العـام ترتب حقوق والتزامسات لأطر اف هذه العلاقة

$$
\text { العقدية والغير. }
$$

ع ـ للمستفيدين من خدمات المرفق العام حق الطعن بقرارات التفويض للدى القضاء

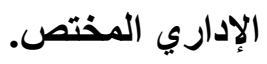

هـ - إن عقود تفويض المرفق العام، هي عقود إداريـة من نوع جديد تبرمها السلطة الاداريـة بسلطتها التقديريـة ولامعقب عليها في استخدام هذه السلطة من حيث

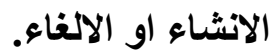




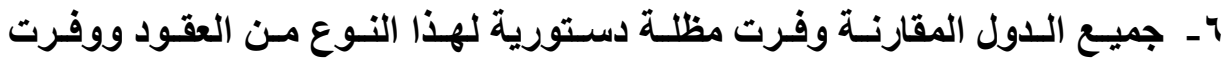

الضمانات اللازمة ايضا حتى لايتم اساءه استخذام السلطة من قبل الادارة.

ثانيًا: التوصيات:

وفي ضوء ما تقام في هذا البحث، أرى ضرورة مراعاة وتنفيذ ما يأتي: ا- ق قيـام دول العالم الثالث ولا سيما الأردن، بضرورة وضع كراسة شروط تتضمن

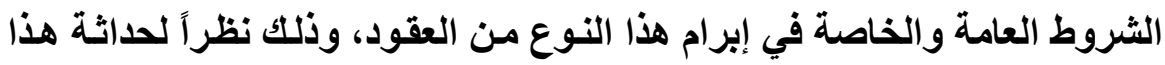

النوع من العقود، ولحاجة الدول إليه.

r- - يؤيد الباحث التفويض الفرعي للمرفق العام، شريطة أن يكون ذلك المرفق قابلاً

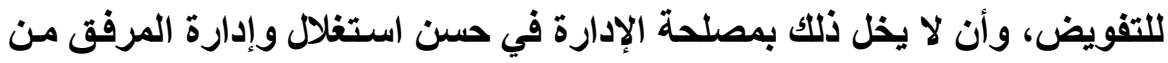
قبل الملتزم، لأنه في معظم عقود التفويض يتم إبرام سلسلة كثيرة من العقود المتشابكة بين الملتزم والمقاولين أو الموردين وهو الأمر الذي يعني تفويض

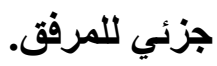
ץ- ضرورة الاستفادة من عقود التفويض المبرمة في فرنسا، وذلكك عند قيام الإدارة بابرام عقد تفويض مرفق عام، نظراً لتمحور هذه الفكرة في القانون الفرنسي. ع - قيام الدولة بصياغة شروط دقيقة تحقق حقوق والتزامات أطراف هذه العقود. هـ ـ يؤكد الباحث على ان التفويض في المرافق العامـة المحلية أو المرافق العامـة

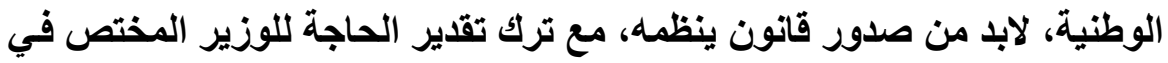
عقود المرافق الوطنيـة، وتقدير الحاجـة للمجلس المحلي في عقدود الوحدات المحلية والمرافق الاقليمية. 
צ- يؤكد الباحث على ان تفويض المرفق العـام الى شركات الاقتصاد المختلط، فيه. تحقيق مصلحة الإدارة في حسن إدارة المرفق وحسن استغلاله على الوجـه الأمثل

$$
\text { وتطبيق قواعد العقود الخاصة عليه. }
$$

V- ضرورة وجود هيئة تسمى هيئة تفويض المرافق العامة سواء كانت محلية أو قوميـة، ويكون في هذه الهيئة عدد من الاختصاصيين الماليين والقانونيين والفنيين، والخبراء العاملين في مختلف المرافق المراد تفويضها، بحيث لا تقدم الدولة على التفويض فيض لمرفق ما إلا بعد أخذ رأي هذه الهيئة، وحتى في حالة موافقة هذه الهيئة على تفويض مرفق، فهي لابـ لها من وضع صياغة دقيقة لعقد التفويض تراعي فيها النواحي

$$
\text { القانونية والمالية والفنية. }
$$

$$
\text { "واخر دعواهم ان الحمد لله رب العالمين" }
$$




\section{المراجع}

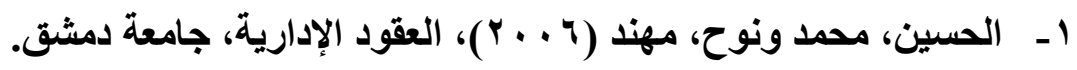

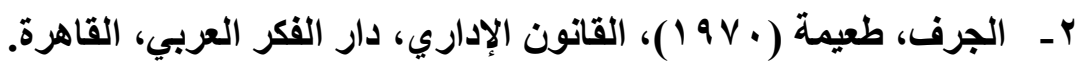
ץ- الشهاوي، إبراهيم (ץ . . ץ)، عقد امتيـاز المرفق العـام BOT، دراسـة مقارنـة، طا، القاهرة.

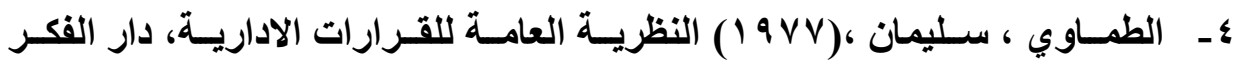

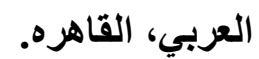

هـ أمسين، محمــ سـعيد حسين (9999 19)، العقود الإداريـة، دار الثقافـة الجامعيـة ،

$$
\text { الإسكندرية. }
$$

$$
\text { צ- قباني، بكر (د.ت)، القانون الإداري ، القاهرة. }
$$

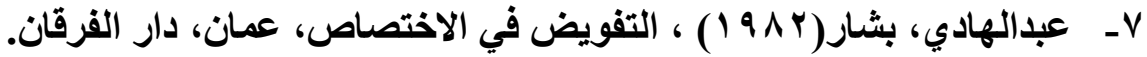
^- ـ شطناوي، علي خطار، القانون الاداري الاردنـي، الكتاب الاول، دار وائل للنشر،

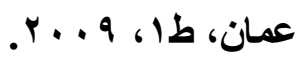

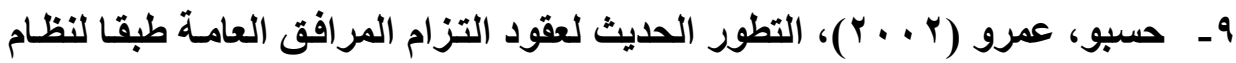
الـ BOT ، دار النهضة العربية، القاهرة.

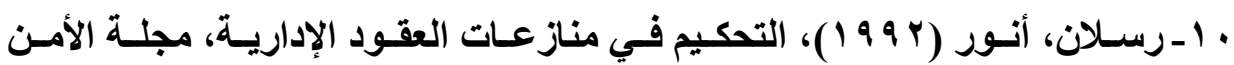

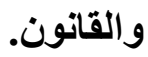


1 اـ شطناوي، علي خطار (7999 (19)، مبادئ القانون الإداري الأردني، الكتاب الثاني، مطبعة الجامعة الأردنية.

r ا ـ عبد الببايع، محمد صلاح عبد البديع (799 (1)، نظام الإدارة المحلية في مصر بين النظرية والتطبيق، القاهرة.

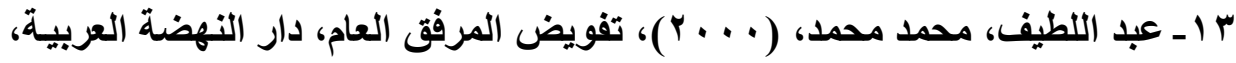
القاهرة.

؛ ا ـ محفوظ، عبد المـنعم، (د ت)الوسـيط في القـانون الاداري، الكتـاب الثـاني،طا، لايوجد دار نشر ومكان نشر، .

ه 1 - شـديفات، فيصل، دور العقود الاداريـة في جلب الاسـتثمارات الاجنبيـة(دراسـة

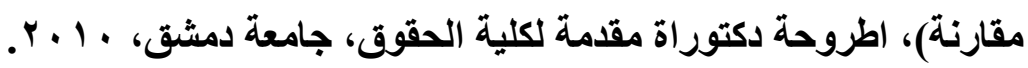

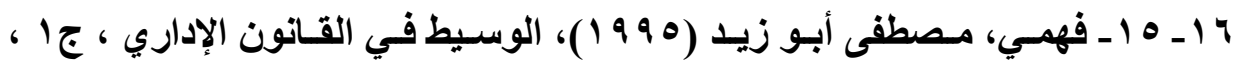
تنظيم الإدارة العامة ، الإسكندرية .

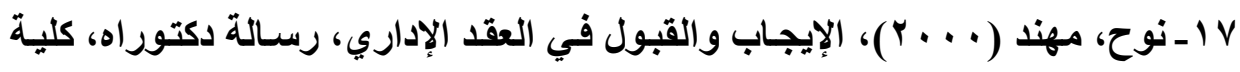
الحقوق، جامعة عين شمس.

1 ا ـ حكم المحكمة الإدارية العليا المصرية في هب يونيو •19 1، مجموعة العقود.

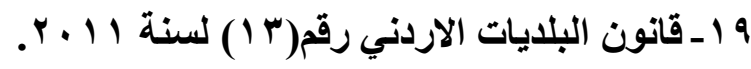

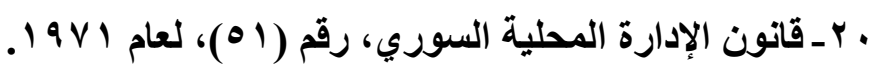

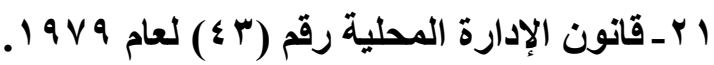

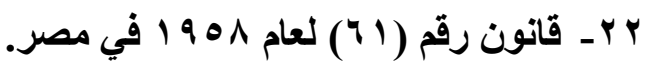




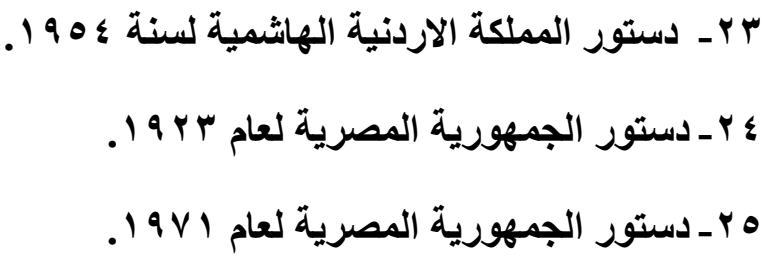

26- A .de Laubadere, F. moderne, p. Delvolve; Traitedes contrats administrative, L.G.D.J, T.1, 1983, n.70.

27- D, chauvaux, Girardot (T.X.), chronigue generale de jurisprudence administvative fran-caise, AJDA, 1996.p ,973 cts.

28- D. Giltard, L'association de La Loi de 1901 et Le spic' Jcp, 1981, L, 3028.s

29- 30- International center for Not-for-profit law, Model provisions for laws Affecting public bennefit org, Washington DC, USA,2002,PP (1-2). Through: http://www.icnl.org/knowledge/pubs/law-PBO-English.pdf.

30- J.B. Auby, C. maugue, J.C.P., 1994, precite, N 14.

31- L. Richer, precite, Remargues sur les enterprises de service public, AJDA, 1997.

32- P. delvolve, Les contradiction de La delegation de service public, A J D A, 1996.

ميلم البحوث القانونيت والإقتصاديت 
33- Ph. Limouzin - Lamothe, La partigue de La delegation de service public, AJDA, 1996.

34- P. prades, Les relations entre Le delegation et Le delegataire, AJDA, 1996.

35- ph. Terheyre, L.a nation de converntion de delegation precite.

36- C.C., 25 juillet 1984, N. 176 DC, Rec..

37- C.E., Assemble generale, 9 mars 1995, section des travaux publics, rapport precite, P. 399: " La Loi inclut dans son chanp d' application les cas ou Le service public est delegue par une authorite chargee de $I^{\prime}$ organization du service aune personne qui recoit pour mission de L'executter".

38- C.E., janvier 1995, ville de paris, Rec..

39- C.E., 15 juin 1994, syndicab intercommoned des transport' ue La region de douai, Rec.

40- C.E., 10 janvier 1992, Assocaiation des usagers del eau de pey, Rec..

41- C.E., avis, section de I' Interieur lonov, 1993, rapp, n. 45. 
42- C.E., 20 juillet 1990, ville de me lun, AJDA, 1990, p. 820, conc IM pochard: D. 1991, P. 578, note G vlacho; Jcp, 1991, n. 21663, note E. fatome.

43- C,E,Iev juillet 1936,veyre,aec,.

44- C,E, juin 1989, Associabion Etudes et consommabion CFDT, Aec.

45- C.E., 4 aout 1905 , mavtir, Rec.

46- T.C., 19 Ferrier, 1990, Espicc. C. / Institut national de la consommation AJDA, 1990, P. 468, cancl Stirn. 